\title{
Modelling the cultivation and bioremediation potential of the kelp Saccharina latissima in close proximity to an exposed salmon farm in Norway
}

\author{
Ole Jacob Broch ${ }^{1,2, *}$, Ingrid Helene Ellingsen ${ }^{1}$, Silje Forbord ${ }^{1,2}$, Xinxin Wang $^{3}$, \\ Zsolt Volent ${ }^{1}$, Morten Omholt Alver ${ }^{1,4}$, Aleksander Handå ${ }^{1,2}$, Kjersti Andresen ${ }^{3}$, \\ Dag Slagstad ${ }^{1}$, Kjell Inge Reitan ${ }^{1,2}$, Yngvar Olsen ${ }^{1,2,3}$, Jorunn Skjermo ${ }^{1,2}$ \\ ${ }^{1}$ SINTEF Fisheries and Aquaculture, PO Box 4762 Sluppen, 7465 Trondheim, Norway \\ ${ }^{2}$ Norwegian Seaweed Technology Center, c/o SINTEF Fisheries and Aquaculture, PO Box 4762 Sluppen, 7465 Trondheim, \\ Norway \\ ${ }^{3}$ Department of Biology, Centre of Fisheries and Aquaculture, and ${ }^{4}$ Department of Engineering Cybernetics, \\ Norwegian University of Science and Technology (NTNU), 7491 Trondheim, Norway
}

\begin{abstract}
A 3-dimensional hydrodynamic-ecological model system (SINMOD) was used to estimate the full-scale cultivation potential of the brown alga Saccharina latissima in integrated multi-trophic aquaculture (IMTA) with Atlantic salmon Salmo salar. A previously developed model for the frond size and composition (carbon and nitrogen content) of $S$. latissima sporophytes was adjusted to data from an outdoor mesocosm growth experiment and then coupled and run online with the 3-dimensional model system. Results from simulations were compared with data from an IMTA field experiment, providing partial validation of the hydrodynamic-ecologicalkelp model system. The model system was applied to study the large-scale cultivation potential of $S$. latissima in IMTA with salmon and to quantify its seasonal bioremediation potential. The results suggest a possible yield of $75 \mathrm{t}$ fresh weight $S$. latissima $\mathrm{ha}^{-1}$ in 4 mo (February to June) and about $170 \mathrm{t}$ fresh weight ha ${ }^{-1}$ in 10 mo (August to June). The results further suggest that the net nitrogen consumption of a 1 ha $S$. latissima installation in the vicinity of a fish farm producing approximately $5000 \mathrm{t}$ salmon in a production cycle is about $0.36(0.15) \mathrm{t} \mathrm{NH}_{4}{ }^{+}-\mathrm{N}$, or a removal of $0.34 \%$ $(0.41 \%)$ of the dissolved inorganic nitrogen effluent with a cultivation period from August (February) to June. Due to the differing seasonal growth patterns of fish and kelp, there was a mismatch between the maximum effluent of $\mathrm{NH}_{4}{ }^{+}-\mathrm{N}$ from the fish farm and the maximum uptake rates in S. latissima.
\end{abstract}

KEY WORDS: Saccharina latissima Integrated multi-trophic aquaculture $\cdot$ Mathematical model $\cdot$ Bioremediation $\cdot$ High resolution ecological model $\cdot$ Salmon farming $\cdot$ Marine biomass

\section{INTRODUCTION}

Norway is the leading country for aquaculture production of salmonic species worldwide (mainly Atlantic salmon Salmo salar; FAO 2012). Mass-balance models indicate that $45 \%$ of the nitrogen released from the salmon industry to Norwegian coastal waters, totaling about $50000 \mathrm{t} \mathrm{N} \mathrm{yr}^{-1}$, is released as dis-

*Email: ole.jacob.broch@sintef.no solved inorganic nitrogen (DIN) (Wang et al. 2012). Thus aquaculture is one of the largest sources of DIN effluents to Norwegian coastal waters (Skarbøvik et al. 2012). There are concerns that such effluents may have a negative impact on the marine ecosystem (Cloern 2001, Skogen et al. 2009). To mitigate the potentially negative effects of salmon farming it is suggested to cultivate, for example, mussels and kelp

() The authors 2013. Open Access under Creative Commons by Attribution Licence. Use, distribution and reproduction are unrestricted. Authors and original publication must be credited. 
alongside the salmon in integrated multi-trophic aquaculture (IMTA) that might also add value to the overall production (Chopin et al. 2001, Troell et al. 2009). Despite the considerable production of $>1$ mil-

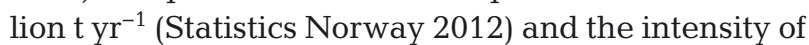
Norwegian salmon production, only a few successful small-scale IMTA trials have been carried out with mussels and kelp (Handå et al. 2012). As nitrogen (mainly in the forms of $\mathrm{NO}_{3}{ }^{-}$and $\mathrm{NH}_{4}{ }^{+}$) is considered the limiting nutrient for macro- and microalgae in the eastern North Atlantic, the potential for salmon-driven IMTA in northern Europe appears to be high (Wang et al. 2012), but the actual full-scale possibilities and benefits remain yet to be quantified.

The main purpose of the present paper is to contribute to quantifying the production potential of Saccharina latissima (L.) Lane, Mayes, Druehl and Saunders in a 'kelp-salmon' IMTA setting, and to increase the understanding of the interplay among the different seasonal dynamics of salmon biomass, nutrient loading rates and kelp biomass.

A coupled 3-dimensional (3D) hydrodynamic-ecological model system (SINMOD; see e.g. Slagstad \& McClimans 2005, Wassmann et al. 2006) was used to simulate the physical and biological dilution and uptake of DIN released from a salmon farm in midNorway, including site-specific features such as local topography and prevailing hydrographic and biotic conditions. The fish farm itself is located in an exposed, open-water environment. A previously developed model for the growth and composition of Saccharina latissima (Broch \& Slagstad 2012) was adjusted against data from a mesocosm growth experiment and coupled with the ecosystem model. The hydrodynamic-ecological-kelp model system was further partially validated using data from an IMTA field experiment. Finally, the model system was used in a number of simulation experiments investigating the large-scale cultivation and bioremediation potential of $S$. latissima, as well as the seasonal nitrogen uptake rates and effects of IMTA on this commercially attractive kelp species (Holdt \& Kraan 2011, Olsen 2011).

\section{MATERIALS AND METHODS}

\section{Mesocosm growth experiment}

Juvenile Saccharina latissima sporophytes, with frond lengths between 10 and $24 \mathrm{~cm}$, were collected in the subtidal zone at Storsteinan, Trondheimsfjord (Fig. 1A), on 11 and 17 November 2008. The plants were transferred to an outdoor saltwater basin at Trondhjem Biological station (TBS), Norwegian University of Science and Technology (NTNU, Fig. 1A), on 19 November, and were spliced into eight $3 \mathrm{~m}$ long vertical ropes, 6 plants on each rope at depths of $0.5,1,1.5,2,2.5$ and $3 \mathrm{~m}$. The basin is $19 \mathrm{~m}$ long, $9 \mathrm{~m}$ wide and between 2.4 and $3.5 \mathrm{~m}$ deep, with a volume of $504 \mathrm{~m}^{3}$. Seawater is taken from $70 \mathrm{~m}$ depth with a mean water exchange rate of $1001 \mathrm{~min}^{-1}$.

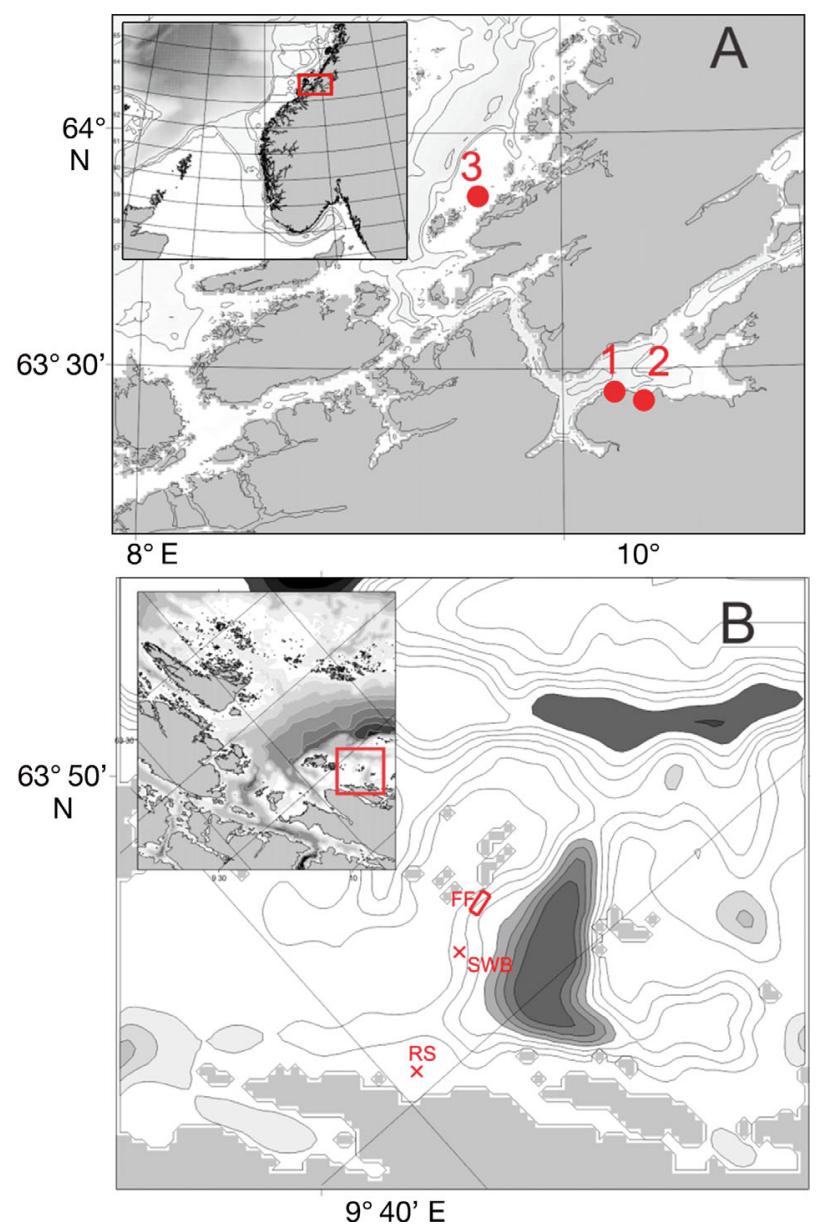

Fig. 1. (A) Map of the coast of southern Norway (inset) indicating the region of the experimental work and the model setups. 1: site (Storsteinan, $63^{\circ} 27^{\prime} \mathrm{N}, 10^{\circ} 15^{\prime}$ E) where Saccharina latissima sporophytes for the mesocosm basin experiment were collected; 2: location of Trondheim Biological Station/NTNU, Trondheim, the site of the mesocosm experiment; 3: location of the ACE fish farm at Tristeinen $\left(63^{\circ}\right.$ $52.250^{\prime} \mathrm{N}, 9^{\circ} 37.022^{\prime} \mathrm{E}$ ), where the integrated multi-trophic aquaculture field experiment was undertaken. The main map is part of the model domain in $800 \mathrm{~m}$ horizontal resolution for the coast of mid-Norway used for nesting to the $160 \mathrm{~m}$ model grid. (B) Model grids in $160 \mathrm{~m}$ horizontal resolution. FF: fish farm; RS: reference station; SWB: Seawatch Buoy used for current measurements. Note the rotation of the model grids in Panel B relative to those in Panel A. The grey curves indicate isobaths 
The projected frond areas of 6 sampled plants were measured monthly by digital photography and analysis. Parallel samples from the meristematic tissue were taken monthly from 6 plants to determine carbon and nitrogen content; in February only 1 single tissue sample for $\mathrm{N}$ content was analysed. The samples were placed in pre-weighed aluminum capsules and dried at $60^{\circ} \mathrm{C}$ for $3 \mathrm{~d}$ before being weighed using a Mettler UM3 micro-weight and finally analysed using a Costech Instrument, Elemental Combustion System Model 4010.

Integrated water samples ( 0 to $3 \mathrm{~m}$ ) were taken from the basin in 2008 on 19 November and 16 December and in 2009 on 18 January, 4 and 18 February, 18 March and 4 and 18 May using a Ruttner water collector (1.7 1). The samples were screened through a 200 $\mu \mathrm{m}$ mesh net to remove larger zooplankton and debris, collected in 101 light-protected containers and stored at $-20^{\circ} \mathrm{C}$ until the $\mathrm{NO}_{3}{ }^{-}$concentration was measured according to Grasshoff et al. (1983).

Light intensity and temperature were recorded at $3.5 \mathrm{~m}$ depth every $10 \mathrm{~min}$ throughout the experiment with Onset HOBO light-intensity loggers in the middle and at 2 sides of the basin. The HOBO loggers were calibrated monthly by measuring the downwelling irradiance at 4 depths (surface, 1, 2 and $3 \mathrm{~m}$ ) using a Ramses ACC spectroradiometer (Trios), measuring from 350 to $950 \mathrm{~nm}$ (Volent et al. 2007), simultaneously with one of the HOBO loggers at the same depths. Diffuse attenuation coefficients were calculated from the Ramses data and used to calculate photosynthetically active radiation (PAR) values from the HOBO loggers at depths of $0,0.5,1,1.5,2$, 2.5 and $3 \mathrm{~m}$ (see Fig. 4A).

\section{Field data and IMTA experiment}

A field experiment with rope cultures of Saccharina latissima deployed in close proximity to the AquaCulture Engineering (ACE) experimental farm at Tristeinen (Bjugn, Norway) was conducted from August 2010 to August 2011 (Fig. 1A,B). During this period, almost $5000 \mathrm{t}$ of salmon were produced at the location, resulting in an effluent of $120 \mathrm{t}$ DIN to the ambient water body (Table 1). The fish were initially set out late in 2009. The ACE fish farm consisted of 10 circular cages of $50 \mathrm{~m}$ diameter, $15 \mathrm{~m}$ deep, fixed within a mooring frame system of dimensions $200 \times$ $500 \mathrm{~m}$.

Saccharina latissima cultures, prepared according to Forbord et al. (2012), were deployed at 2 stations, 1 close to the fish farm (FF) and 1 at a reference station (RS) about $4 \mathrm{~km}$ south of the farm (Fig. 1B), on 19 August 2010 and 21 February 2011. The S. latissima sporophytes were grown on $1 \mathrm{~m}$ long ropes attached at 2, 5 and $8 \mathrm{~m}$ depths to $9 \mathrm{~m}$ long vertical lines. The length $(l)$ and width $(W)$ of the fronds of 10 to 20 randomly selected plants on 3 ropes were measured monthly from 16 September 2010 to 8 August 2011, except in November and July. The kelp growth model uses projected frond area as the main state variable (Broch \& Slagstad 2012). In order to compare the simulation results with the field data, we approximated the frond area $(A)$ by:

$$
A=0.751 W
$$

which is the average of an upper and lower bound for the projected area of an S. latissima frond (Fig. 2).

Fig. 2. Saccharina latissima. Approximations of the area of fronds (A). The area of the red rectangle is length $\times$ width $=l w$, while that of the inscribed red quadrilateral, a shape roughly similar to that of a frond, is $1 w / 2$. We then assume that $l W / 2 \leq A \leq l W$ and use the average of the upper and lower bounds for $A$ to approximate frond area

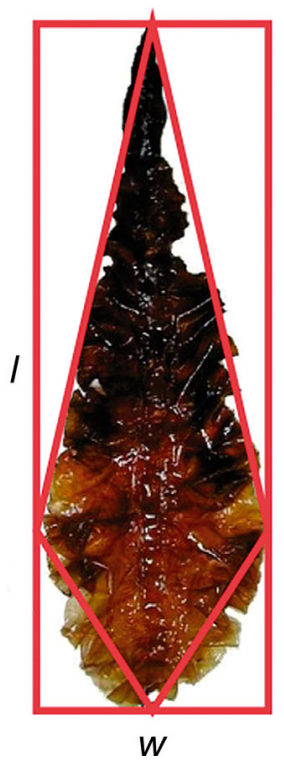

Table 1. Salmo salar. Corrected monthly salmon production and dissolved inorganic nitrogen $\left(\mathrm{NH}_{4}{ }^{+}-\mathrm{N}\right)(\mathrm{both}$ in $\mathrm{t})$ released from the AquaCulture Engineering salmon farm from June 2010 to June 2011

\begin{tabular}{|c|c|c|c|c|c|c|c|c|c|c|c|c|c|c|}
\hline & \multicolumn{7}{|c|}{-2010} & \multicolumn{6}{|c|}{-2011} & \multirow[b]{2}{*}{ Total } \\
\hline & Jun & Jul & Aug & Sep & Oct & Nov & Dec & Jan & Feb & Mar & Apr & May & Jun & \\
\hline Salmon production & 85 & 156 & 376 & 574 & 487 & 427 & 148 & 492 & 428 & 494 & 360 & 489 & 441 & 4957 \\
\hline $\mathrm{NH}_{4}{ }^{+}-\mathrm{N}$ released & 1.37 & 3.41 & 12.33 & 12.92 & 13.21 & 10.94 & 3.56 & 11.82 & 12.55 & 10.79 & 7.90 & 10.09 & 9.33 & 120.22 \\
\hline
\end{tabular}


The averages and standard deviations of the frond areas from the field and simulation data were compared (cf. 'Simulation of the IMTA field experiment' below).

Tissue samples for determination of carbon and nitrogen content and integrated ( 0 to $8 \mathrm{~m}$ ) water samples were collected monthly. The water samples were taken using a Ramberg water collector and prefiltered through a $200 \mu \mathrm{m}$ net prior to a second filtration on pre-combusted, acid-washed Whatman GF/F filters. The concentration of $\mathrm{NH}_{4}{ }^{+} \mathrm{N}$ and $\mathrm{NO}_{3}{ }^{-}-\mathrm{N}$ were determined in parallel by a fluorescence detector (DFL-10; Kerouel \& Aminot 1997) and by a flow analyser with O.I. Analytical cartridge Part A002603, respectively.

Current measurements were made in January to May 2012, with an acoustic Doppler current profiler (ADCP) mounted below a Fugro Oceanor Seawatch Midi 185 buoy pointing downwards (SWB in Fig. 1B). Velocities at 13 depth levels ranging from 4.5 to $53.5 \mathrm{~m}$ were recorded hourly, with the sensor averaging data gathered over a 10 min interval.

\section{D ecological model system SINMOD}

SINMOD is a coupled 3D hydrodynamicecological model system (Støle-Hansen \& Slagstad 1991, Slagstad \& McClimans 2005, Wassmann et al. 2006). The hydrodynamic model is based on the primitive Navier-Stokes equations solved by a finite difference scheme. The model uses $z$-coordinates, i.e. each model depth level has a fixed thickness, except for the surface level and the one closest to the bottom. The ecological component (Wassmann et al. 2006) has 13 state variables in addition to the Saccharina latissima component (Fig. 3).

The model was run from 28 May 2010 to 31 July 2011, using a horizontal resolution of $160 \mathrm{~m}$ for a region of the coastal waters off Trøndelag, Norway (Fig. 1B). Boundary conditions were generated in a 3step nesting procedure, running models of increasingly finer grids from 20000 to $160 \mathrm{~m}$ horizontal resolution. The 20000 and $4000 \mathrm{~m}$ model domains encompass the Arctic Ocean and Nordic seas (Ellingsen et al. 2009), respectively, while the $800 \mathrm{~m}$ model domain covers the Norwegian coast from $61^{\circ} 53^{\prime} \mathrm{N}$, $4^{\circ} 46^{\prime} \mathrm{E}$ to $66^{\circ} 22^{\prime} \mathrm{N}, 12^{\circ} 8^{\prime} \mathrm{E}$. SINMOD has been shown to resolve the circulation dynamics well for the Norwegian shelf off northern Norway (Slagstad et al. 1999, Skarðhamar \& Svendsen 2005, Anon 2011). The $160 \mathrm{~m}$ model used 28 vertical layers, with thickness ranging from 0.5 to $50 \mathrm{~m}$. The greatest depth in the model domain was $610 \mathrm{~m}$.

Atmospheric forcing was applied using data from ECMWF ERA-Interim (Dee et al. 2011), and freshwater discharges from rivers and diffuse discharges from land were provided by NVE (Norwegian Water Resources and Energy Directorate, www.nve.no).

For computational efficiency a sub-domain of the $160 \mathrm{~m}$ model domain surrounding the fish farm was established (Fig. 1B). Boundary conditions for this smaller model domain were generated by the larger $160 \mathrm{~m}$ model. The smaller model domain was run in

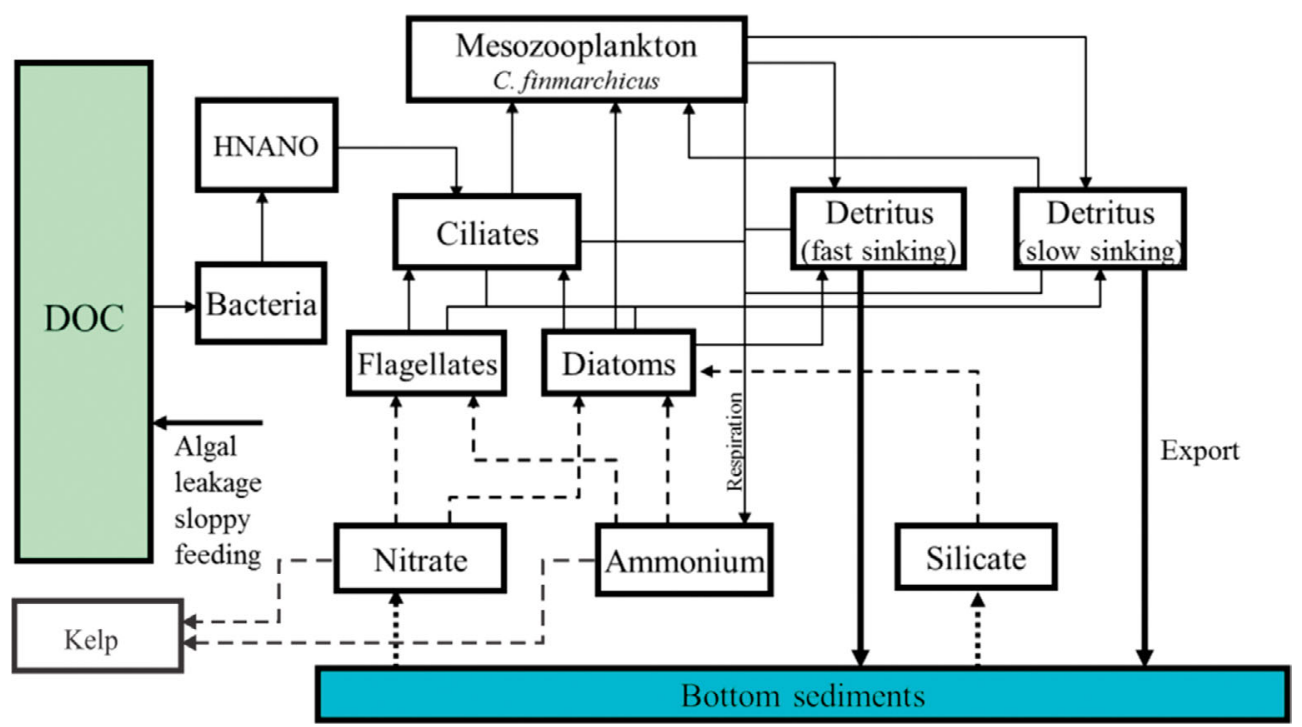

Fig. 3. SINMOD ecosystem model structure, adapted from Wassmann et al. (2006). DOC: dissolved organic carbon; HNANO: heterotrophic nanoflagellates 
3D and coupled with the kelp model (see following subsection) using a time step of $40 \mathrm{~s}$.

\section{Saccharina latissima growth model}

The individual-based growth model for $S$. latissima developed by Broch \& Slagstad (2012) uses 3 state variables: projected frond area and nitrogen and carbon reserves ( $N$ and $C$, respectively). Net increases or decreases in frond area result from a combination of growth and erosion of the frond. Fresh weight (FW) and dry weight (DW) as well as carbon and nitrogen content of the frond are calculated from the state variables. The structural part of the frond is assumed to have a fixed stoichiometry, but changes in reserve levels may lead to overall changes in the stoichiometry (e.g. C:N ratio and water content) of the organism. The model uses 4 environmental (input) variables: irradiance (PAR), water temperature, ambient nutrient concentration $\left(\mathrm{NO}_{3}{ }^{-}\right.$and $\left.\mathrm{NH}_{4}{ }^{+}\right)$ and water current speed. The change in day length is used to adjust growth rates (photoperiodic forcing).

A change made to the kelp growth model as described by Broch \& Slagstad (2012) is that the respiration per frond area resp has been divided into basal and activity respiration (Lobban \& Harrison 1994):

$$
\text { resp }=\operatorname{resp}_{B}+\operatorname{resp}_{A}
$$

The basal respiration $\operatorname{resp}_{\mathrm{B}}$ is a function of ambient temperature $\left(T,{ }^{\circ} \mathrm{K}\right)$

$$
\operatorname{resp}_{\mathrm{B}}=R_{\mathrm{B}} \exp \left(T_{\mathrm{Arr}} / T_{1}-T_{\mathrm{Arr}} / T\right)
$$

while the activity respiration $\operatorname{resp}_{\mathrm{A}}$ is a function of temperature, the area specific growth and uptake rates ( $\mu$ and $J$, respectively):

$$
\operatorname{resp}_{\mathrm{A}}=R_{\mathrm{A}}\left(\mu / \mu_{\max }+J / J_{\max }\right) \exp \left(T_{\text {Arr }} / T_{1}-T_{\text {Arr }} / T\right)
$$

Here, $T_{1}$ and $T_{\text {Arr }}$ are reference and Arrhenius temperatures $\left({ }^{\circ} \mathrm{K}\right)$, respectively (e.g. Kooijman 2000), while $\mu_{\max }$ and $J_{\max }$ are the maximal area-specific growth and uptake rates as functions of the present growth model state variables (Broch \& Slagstad 2012). Previously, respiration was assumed to be temperature dependent only (parameters $R_{\mathrm{A}}$ and $R_{\mathrm{B}}$ in Table 2 ; see Broch \& Slagstad 2012 for the other notation and parameters).

Relative growth and uptake rates for small and young sporophytes are high (Bolton \& Lüning 1982). For the early stage $\left(A<2 \mathrm{~cm}^{2}\right)$ area-specific growth rates, nutrient uptake and photosynthetic rates were multiplied by 8,12 and 5 , respectively. The values were chosen so that the simulated frond size increased from 0.2 to $3.55 \mathrm{~cm}^{2}$ from 19 August to 16 September at the FF location (Table 2). At deployment, sporophytes were 5 to $10 \mathrm{~mm}$ long (Forbord et al. 2012).

A standard forward Euler method for solving the differential equations of the kelp model was used.

\section{Simulations}

An overview of all the simulations with brief descriptions of the scenarios and Saccharina latissima initial conditions is given in Table 2 . When convenient, we will refer to each set of simulations simply as A, B, C, D, and E.

\section{Adjustment of model to mesocosm data} (Simulation A)

The original Saccharina latissima growth model parameters (Broch \& Slagstad 2012) were adjusted to fit the growth data described in the 'Mesocosm growth experiment' above. The environmental data recorded in the experiment were used as input, except that the current speed was set to a constant $0.01 \mathrm{~m} \mathrm{~s}^{-1}$. Temperature and PAR were sampled every 10 min (cf. 'Mesocosm growth experiment' above), while the $\mathrm{NO}_{3}{ }^{-}$concentration was sampled monthly (see Fig. 4A,B). The observed $\mathrm{NO}_{3}{ }^{-}$concentrations were interpolated to $10 \mathrm{~min}$ intervals, the time step used in the simulations. The model was fit to the data by using the sums of the squares of the relative differences between simulated and measured values for frond area, nitrogen and carbon content of the algae at the dates sampled, and changes in frond area from one sampling to the next, as a measure of the fit.

\section{Simulation of the IMTA field experiment (Simulations B)}

The growth of the Saccharina latissima cultures deployed on 19 August 2010, was simulated for the reference station (RS) and for the station at the southwestern corner of the fish farm (FF, Fig. 1B). The growth of the cultures deployed on 21 February 2011 was simulated for the FF station only. No data on frond area, nitrogen content, or carbon content were recorded at the time of deployment. For the plants deployed in August, the corresponding simulations were started on 16 September, the date of first sampling, using the measured values for that date. A total of 60 plants for each depth segment $(2,5$ and $8 \mathrm{~m}$ ) were used in the simulations. At the RS, all 


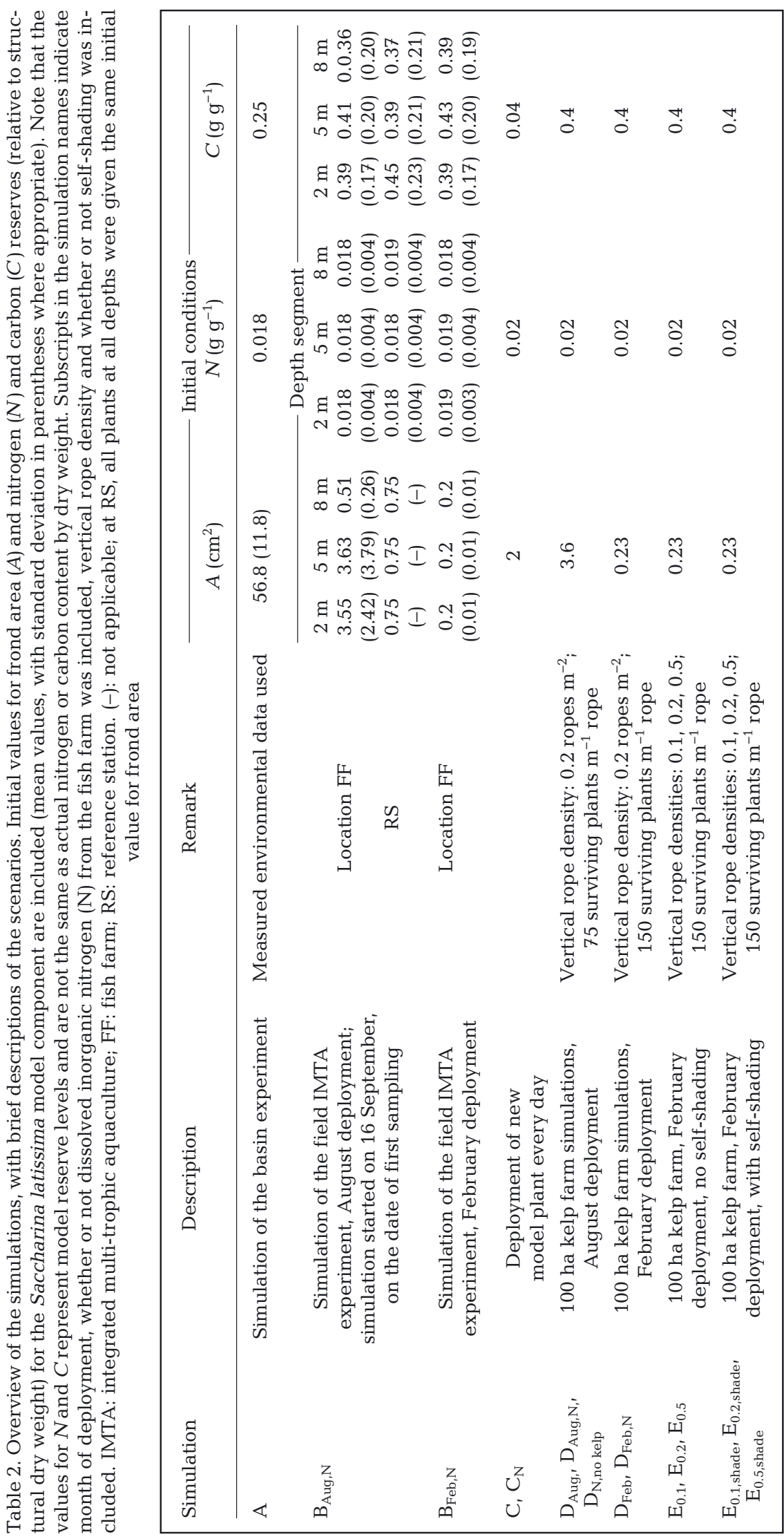

plants at all depths were given the same initial value for frond area (Table 2). No recordings of the sizes of the plants deployed in February were made until 3 May. Pseudo-randomly generated initial values for the frond areas were used in this case (Table 2). Initial values for $N$ and $C$ reserve sizes were pseudorandomly generated in all the simulations (Table 2). In Simulations B to E, figures for DIN effluents from the fish farm were calculated from monthly reports on feed usage and corrected biomass production using a massbalance model (Wang et al. 2012), and the DIN effluents were assumed to vary according to the data in Table 1. The DIN was released from 4 model grid cells between 5 and $15 \mathrm{~m}$ depths - as there is no general rule as to the depth at which salmon school (Oppedal et al. 2011) and was added to the $\mathrm{NH}_{4}{ }^{+}-\mathrm{N}$ model component.

\section{Seasonal effects of IMTA (Simulations C)}

The connections between seasonal growth patterns of SaCcharina latissima and fish farm nutrient loading rates were investigated by running 2 simulations with one 'model plant' being added with the same initial conditions every day from 1 June 2010 to 31 May 2011 (Table 2). One simulation was run with and the other without the nutrient loading from the fish farm. The model plants were assumed to be located at $5 \mathrm{~m}$ depth at the north-western corner of the fish farm, the point outside the mooring frame with the highest average simulated effluent $\mathrm{NH}_{4}{ }^{+}$concentration (see Fig. 7). 
Simulating large-scale kelp production (Simulations D)

The large-scale biomass production and the nitrogen assimilation potential of Saccharina latissima cultures deployed in August and February were simulated by 'deploying' plants in 40 horizontal grid cells adjacent to the fish farm (see Fig. 15), covering
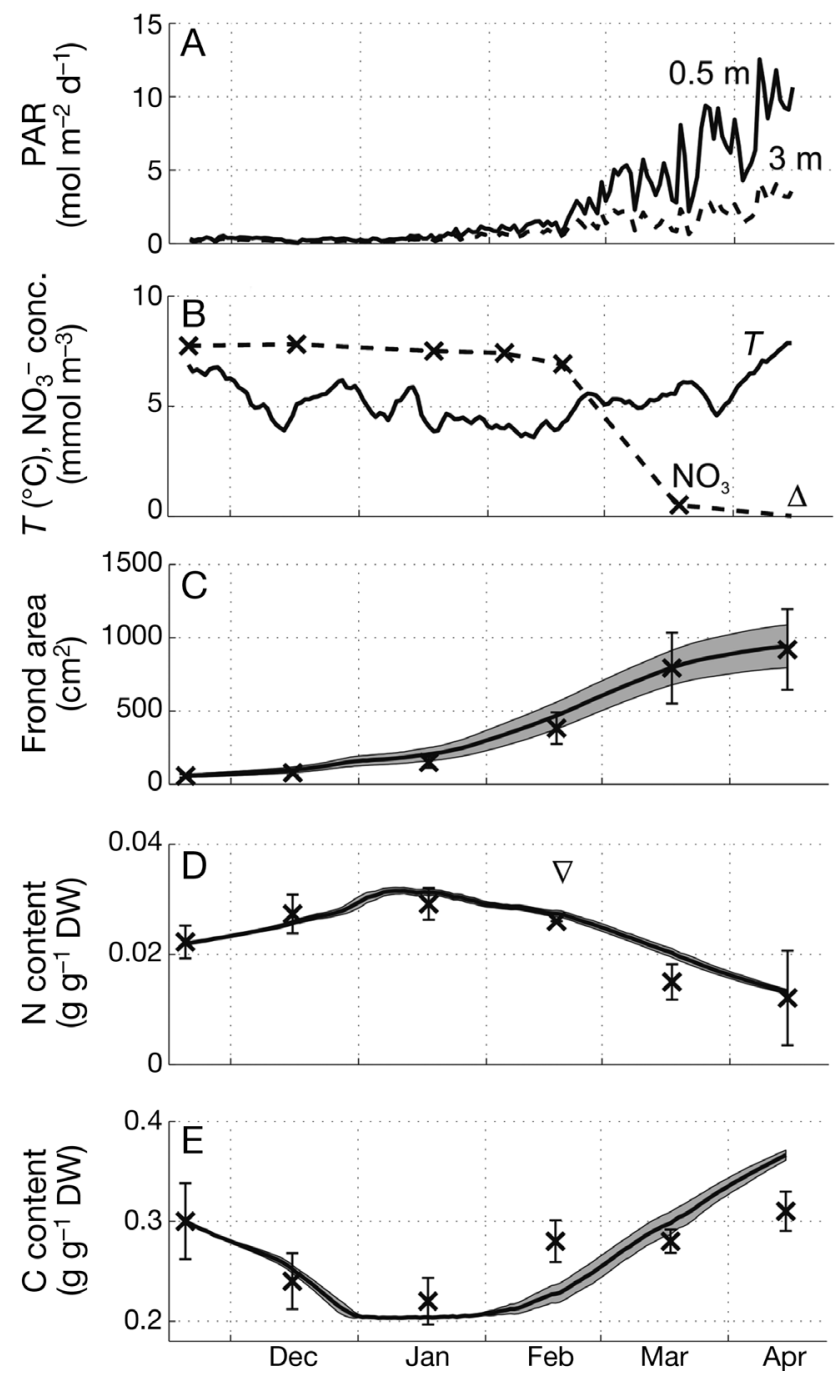

Fig. 4. Data from the mesocosm basin growth experiment and corresponding model simulations (see Table 2). (A) Total daily photosynthetically active radiation (PAR) at 0.5 and $3 \mathrm{~m}$ depths. (B) Temperature ( $T$, daily average values, continuous line) and integrated (0 to $3 \mathrm{~m}$ ) $\mathrm{NO}_{3}{ }^{-}$concentration (crosses, dashed line). The $\Delta$ in April indicates a value (0) not actually recorded, but used in the simulations. Average measured ( $\mathrm{n}=6$ [except $\nabla, \mathrm{n}=1$ ], crosses) and simulated ( $\mathrm{n}=6$, continuous lines) values for $(\mathrm{C})$ frond area and for (D) nitrogen and (E) carbon content of Saccharina latissima sporophytes. Error bars indicate sample mean standard deviations of the measurements, while shaded grey regions are sample mean standard deviations for the simulations a total area of approximately $1 \mathrm{~km}^{2}$ or $100 \mathrm{ha}$. The plants were assumed to be cultivated from 1 to $6 \mathrm{~m}$ depth on vertically hanging ropes attached to long lines with a density of 0.2 vertical ropes $\mathrm{m}^{-2}$. The density of surviving plants was assumed to be 150 plants $\mathrm{m}^{-1}$ rope for the February deployments and 75 plants $\mathrm{m}^{-1}$ rope for the August deployments, assuming higher total mortality among the August plants because they were in the water for a longer period. Initial conditions are given in Table 2. The plants in each grid cell were represented by super individuals (Scheffer et al. 1995), i.e. all the plants in each cell had the same $A, N$ and $C$ values, while the density of individuals was used to calculate total nutrient uptake and light shading in each model grid cell. The kelp model was coupled with the ecosystem model, so that the amounts of $\mathrm{NO}_{3}{ }^{-}$and $\mathrm{NH}_{4}{ }^{+}$absorbed by the $S$. latissima plants were taken into account. For each of the deployments (August, February), simulations with and without DIN effluents from the salmon farm were run. A simulation with DIN effluents, but no kelp cultures was also run $\left(\mathrm{D}_{\mathrm{N}, \text { no kelpi }}\right.$ Table 2$)$.

\section{Effects of light shading (Simulations E)}

Simulations with and without light shading effects of the Saccharina latissima plants for the 100 ha February deployments were run. In the simulations with light shading, the light attenuation coefficient $k$ in a model grid cell was calculated as:

$$
k=k_{\text {eco }}+k_{\text {kelp }}
$$

Here, $k_{\text {eco }}$ is the sum of the background light attenuation and the light attenuation due to the phytoplankton and detritus densities (Wassmann et al. 2006), and $k_{\mathrm{kelp}}$ is the attenuation due to the S. latissima cultures depending on plant size, vertical rope density and plant density within each rope (Broch \& Slagstad 2012). Three densities of vertically hanging ropes were considered: $0.1,0.2$ and 0.5 vertical ropes $\mathrm{m}^{-2}$.

\section{RESULTS}

\section{Mesocosm experiment and model fit (Simulation A)}

The main results from the mesocosm experiment and corresponding model simulations (Simulation A, Table 2) are presented in Fig. $4 \mathrm{~A}-\mathrm{E}$. The $\mathrm{NO}_{3}{ }^{-}$concentration in the basin appeared steady at around $7 \mathrm{mmol} \mathrm{m}^{-3}$ from November to February and to decrease from 6.9 to $0.5 \mathrm{mmol} \mathrm{m}^{-3}$ from 18 February to 
18 March (Fig. 4B). Water samples from 4 and 18 May contained no detectable $\mathrm{NO}_{3}{ }^{-}$, and, in the model fit simulations, a value of 0 in April was assumed. The measured nitrogen content of the frond tissue sampled also decreased from January onwards (Fig. 4D). Daily integrated PAR values increased from the end of February (Fig. 4A) and were negatively correlated with the interpolated daily $\mathrm{NO}_{3}{ }^{-}$concentration (linear sample correlation coefficient $r=-0.9$; Fig. 4B). The new and old values of the kelp model parameters subject to adjustment are presented in Table 3. A quantitative comparison between model and measured data is presented in Table 4, cf. Fig. 4C-E.

\section{Environmental data from SINMOD}

Measured and simulated currents at $14.5 \mathrm{~m}$ depth at the SWB location (Fig. 1B) over a period of $7 \mathrm{~d}$ in January 2012 are shown in Fig. 5. The model followed the trends in the measurements, but did not capture highfrequency variability in the measured current data. Harmonic analysis of data from both the model and the ADCP observations showed that tidal currents at the location were weak $\left(<0.05 \mathrm{~m} \mathrm{~s}^{-1}\right)$. The directions of simulated and measured mean velocities (January to May 2012) were 48 and 67 degrees, respectively.
Simulated integrated (0 to $8 \mathrm{~m}$ ) $\mathrm{NH}_{4}{ }^{+}-\mathrm{N}$ concentrations at the FF location varied, with events of elevated values 1 to 2 times a month (Fig. 6A). The monthly mean simulated $\mathrm{NH}_{4}{ }^{+}-\mathrm{N}$ concentration was $<1 \mathrm{mmol} \mathrm{m}^{-3}$ and of the same order of magnitude as the observations. The simulated $\mathrm{NO}_{3}{ }^{-}-\mathrm{N}$ concentrations showed a strong seasonal signal: nutrients became depleted in April, while the concentrations increased again in autumn (from October; Fig. 6B). The simulated data were in accordance with observations during spring and summer (from April to October), but were higher during late autumn and winter. The measured $\mathrm{NO}_{3}{ }^{-}$concentration stayed around $2 \mathrm{mmol} \mathrm{N} \mathrm{m}^{-3}$ during autumn, and increased steadily to a maximum of $6.4 \mathrm{mmol} \mathrm{N} \mathrm{m}^{-3}$ in late April/early May.

In Fig. 7 the plume of DIN from the fish farm is clearly visible against the simulated background $\mathrm{NH}_{4}{ }^{+}-\mathrm{N}$ values. From the plume, the general direction of the water current through/from the fish farm appeared to be north-north-east (NNE).

\section{Partial model validation (Simulations B)}

The model captured the general trend in frond area growth at 2 and $5 \mathrm{~m}$ depths, both at the FF and

Table 3. New (present paper) and old (Broch \& Slagstad 2012) values for parameters adjusted by tuning the Saccharina latissima model to the data (cf. 'Mesocosm growth experiment'). Only the parameters that were changed have been included here. For notations and the rest of the parameters, see Broch \& Slagstad (2012)

\begin{tabular}{|c|c|c|c|c|}
\hline Parameter & New value & Old value & Unit & Notation \\
\hline Size-dependent growth adjustment parameter & 4.5 & 6 & $\mathrm{dm}^{2}$ & $A_{0}$ \\
\hline Photosynthetic efficiency & $4.15 \times 10^{-5}$ & $3.74 \times 10^{-5}$ & g C dm ${ }^{-2} \mathrm{~h}^{-1}\left(\mu \mathrm{mol} \text { photons } \mathrm{m}^{-2} \mathrm{~s}^{-1}\right)^{-1}$ & $\alpha$ \\
\hline Irradiance for maximal photosynthetic rate & 90 & 200 & $\mu \mathrm{mol}$ photons $\mathrm{m}^{-2} \mathrm{~s}^{-1}$ & $I_{\text {sat }}$ \\
\hline Minimal nitrogen reserve & 0.0126 & 0.010 & $\mathrm{~g} \mathrm{~N} \mathrm{~g}^{-1}$ structural mass & $N_{\min }$ \\
\hline Maximal nitrogen reserve & 0.0216 & 0.0220 & $\mathrm{~g} \mathrm{~N} \mathrm{~g}^{-1}$ structural mass & $N_{\max }$ \\
\hline Structural nitrogen content & 0.0146 & 0.010 & $\mathrm{~g} \mathrm{~N} \mathrm{~g}^{-1}$ structural mass & $N_{\text {struct }}$ \\
\hline Structural dry weight per unit area & 0.5 & 0.6 & $\mathrm{~g} \mathrm{dm}^{-2}$ & $k_{A}$ \\
\hline Activity respiration parameter & $1.11 \times 10^{-4}$ & - & $\mathrm{g} \mathrm{C} \mathrm{dm}^{-2} \mathrm{~h}^{-1}$ & $R_{A}$ \\
\hline Basal respiration parameter & $5.57 \times 10^{-5}$ & - & $\mathrm{g} \mathrm{C} \mathrm{dm} \mathrm{m}^{-2} \mathrm{~h}^{-1}$ & $R_{B}$ \\
\hline
\end{tabular}

Table 4. Saccharina latissima. Relative differences $\left.\left[\mathrm{RD}=\left(X_{\text {simulated }}-X_{\text {measured }}\right) / X_{\text {measured }}\right)\right]$ between simulated average (Simulation $A$, see Table 2) and measured average values of frond area $(A)$ and nitrogen $(\mathrm{N})$ and carbon $(\mathrm{C})$ content $\left(\mathrm{g} \mathrm{g} \mathrm{g}^{-1}\right)$ on the sampling dates in the mesocosm experiment. Mean RD and mean absolute RD are also presented. Sample correlations (r) between the simulated and measured mean values are presented in the far right column

\begin{tabular}{|rrrrrrrrc|}
\hline & Dec & Jan & Feb & Mar & Apr & Mean RD & Mean of absolute RD & $\begin{array}{c}\text { Times series correlations between measured } \\
\text { and simulated means (Dec-Apr) (r) }\end{array}$ \\
\hline A & 0.26 & 0.38 & 0.23 & 0.00 & 0.02 & 0.18 & 0.18 & 0.997 \\
$\mathrm{~N}$ & -0.06 & 0.07 & 0.05 & 0.35 & 0.09 & 0.10 & 0.12 & 0.951 \\
$\mathrm{C}$ & 0.05 & -0.07 & -0.19 & 0.06 & 0.18 & 0.01 & 0.11 & 0.818 \\
\hline
\end{tabular}



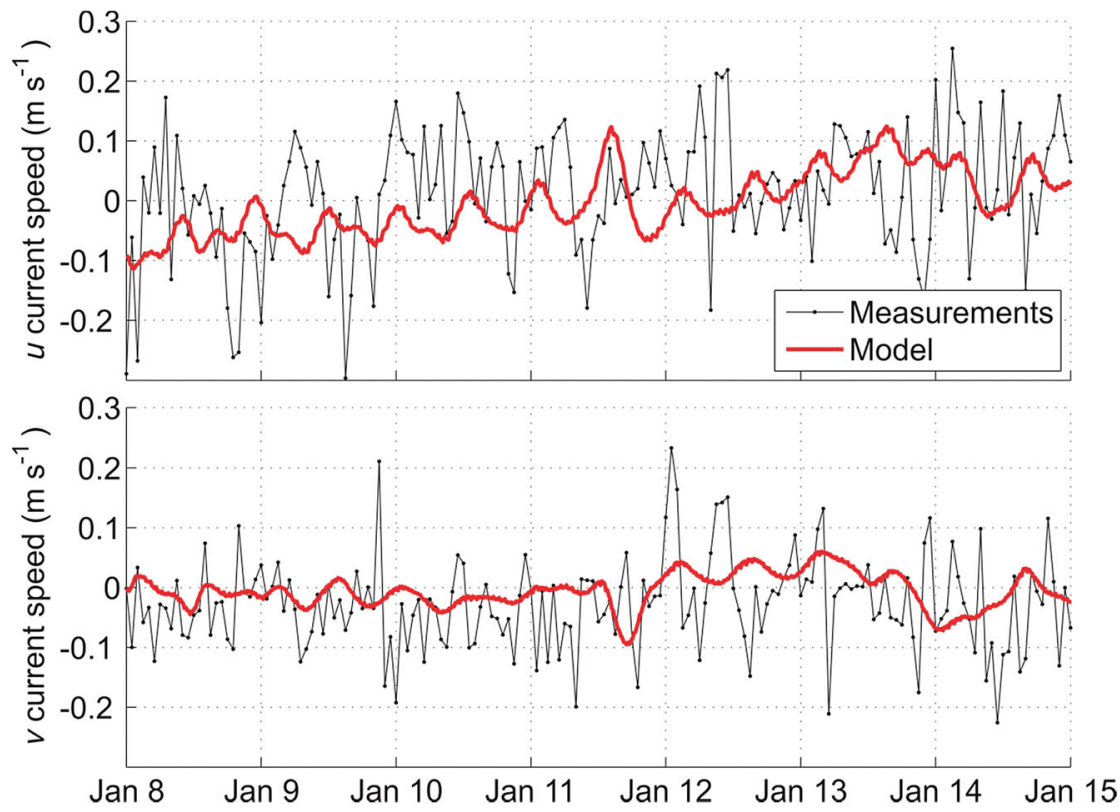

Fig. 5. Comparison of measured (thin black line) and simulated (thick red line) currents at $14.5 \mathrm{~m}$ depth along the model's 2 component directions, $u$ and $v$, at the Seawatch buoy (labelled SWB in Fig. 1B). For SINMOD, hourly data from the 12 to $15 \mathrm{~m}$ depth layer are shown, disregarding elevation, covering the period 8 to 15 January 2012. Measurements were made hourly at $8 \mathrm{~m}$ depth (Figs. $8 \mathrm{C} \& 9 \mathrm{C}$, Table 5). The simulated values for carbon and nitrogen content were of the same magnitudes as the measured values (Fig. 11), and the seasonal trends in composition were coarsely resolved by the model.

\section{Seasonal effects of IMTA (Simulations C)}

The seasonal effect of integrating Saccharina latissima and salmon aquaculture was quantified by the relative increase (RI) in harvested DW of single plants from Simulation $\mathrm{C}$ to Simulation $\mathrm{C}_{\mathrm{N}}$, that is:

$$
\left.\mathrm{RI}=\frac{\left(\mathrm{DW}_{\text {effluent }}-\mathrm{DW}\right. \text { no effluent }}{}\right)
$$

(Fig. 12). The maximum effect was a relative increase of almost $0.8 \mathrm{ob}$ tained by deployment in June and harvest in December. A relative in-
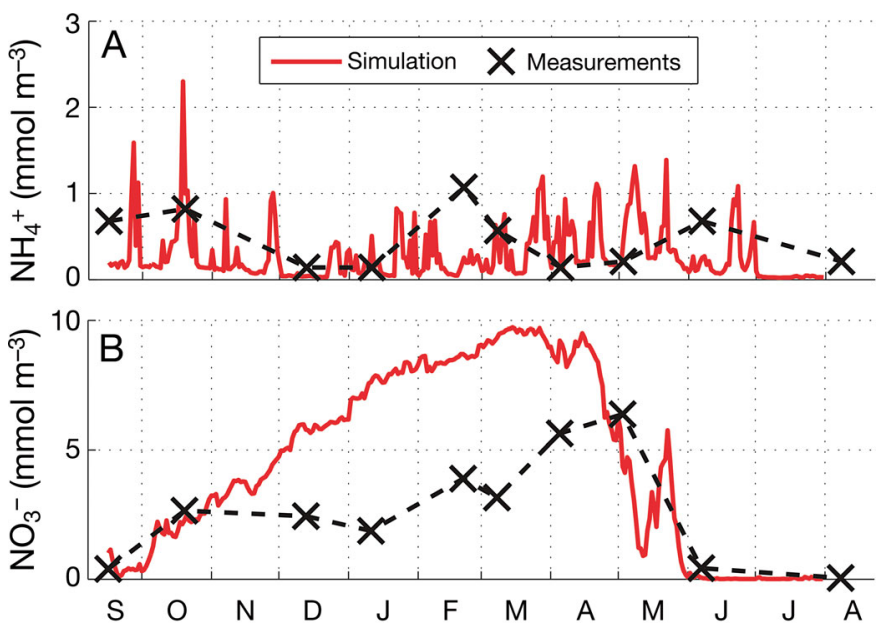

Fig. 6. Time series of simulated (Simulation $\mathrm{B}_{\mathrm{Aug}, \mathrm{N}}$, solid red line) and measured (black crosses and dashed line) integrated (0 to $8 \mathrm{~m}$ ) (A) $\mathrm{NH}_{4}{ }^{4}$ and (B) $\mathrm{NO}_{3}{ }^{-}$concentrations at the fish farm station

RS stations in Simulation $B_{\text {Aug, } N}$ and at all depths in Simulation $\mathrm{B}_{\mathrm{Feb}, \mathrm{N}}$ (Figs. 8, 9 \& 10, Table 5). Simulated frond areas at $2 \mathrm{~m}$ depth in Simulation $\mathrm{B}_{\text {Aug, } \mathrm{N}}$ decreased from early June onwards (Fig. 8A). Simulated frond erosion rates in June/July were not as high as indicated by the measured decrease in frond area from June to August. In Simulation $\mathrm{B}_{\mathrm{Aug}, \mathrm{N}}$ the model over-estimated the frond area at both stations crease of $>0.5$ was obtained by deployment in June to July and harvest from mid-October to mid-February or deployment from late March to early May and harvesting in July. With a fixed harvest date of 15 June corresponding to a horizontal section across Fig. 12, the relative increase in DW from Simulation $\mathrm{C}$ to $\mathrm{C}_{\mathrm{N}}$ was $\sim 0.05$ for deployment in January, 0.05 to 0.08 for deployment in February and 0.09 to 0.28 for deployment in March.

The simulated daily uptake of nitrogen by single kelp individuals as a function of deployment date and cultivation date is shown in Fig. 13, expressed as $30 \mathrm{~d}$ running means of nitrogen uptake as a fraction of the total uptake from the start to the end of the simulation (31 July). These results indicate that the period of main nitrogen uptake was April to May, regardless of the deployment date.

\section{Large-scale farm simulations (Simulations D)}

The growth patterns for biomass of the 100 ha farm simulations were largely the same as for the corresponding simulations of frond areas in the IMTA field experiment (Figs. 8, 9, 10 \& 14A). However, the biomass in Simulations D continued increasing until 31 July, while the corresponding measured frond area decreased from mid-June onwards. 

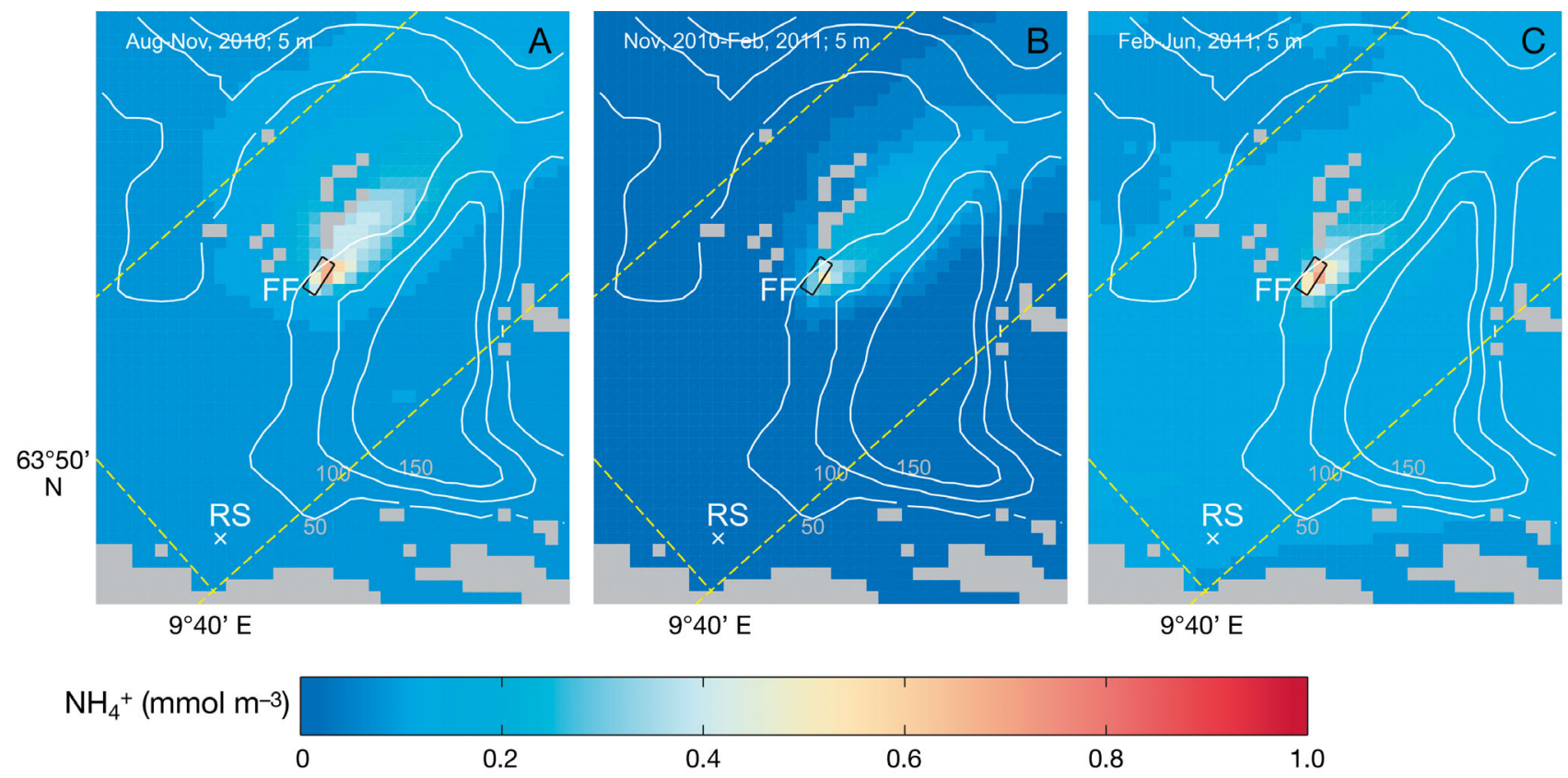

Fig. 7. Average $\mathrm{NH}_{4}{ }^{+}$concentrations at $5 \mathrm{~m}$ depth for 3 periods: (A) August to November 2010, (B) November 2010 to February 2011 and (C) February 2011 to July 2011. White curves are 50, 100 and $150 \mathrm{~m}$ isobaths
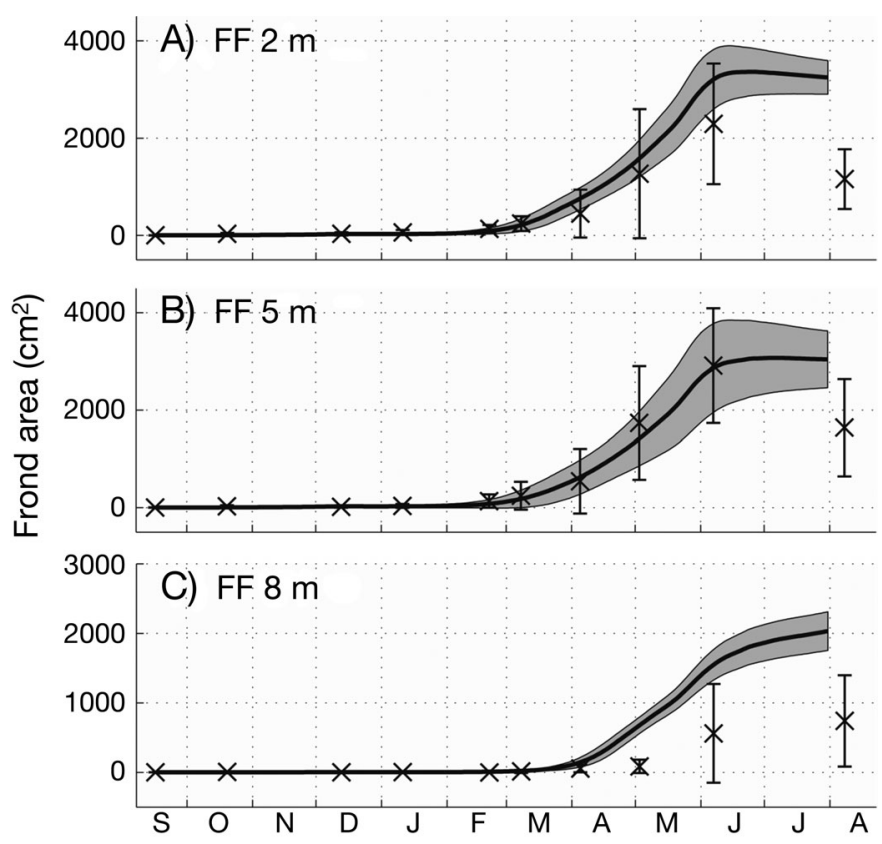

Fig. 8. Saccharina latissima. Average simulated (Simulation $\mathrm{B}_{\mathrm{Aug}, \mathrm{N}}$, continuous lines) and measured (crosses) frond areas $\left(\mathrm{cm}^{2}\right)$ for the August deployment at the fish farm (FF) station (Fig. 1B) at (A) $2 \mathrm{~m}$, (B) $5 \mathrm{~m}$ and (C) $8 \mathrm{~m}$ depth. The shaded regions and error bars indicate standard deviations of simulated and observed values, respectively
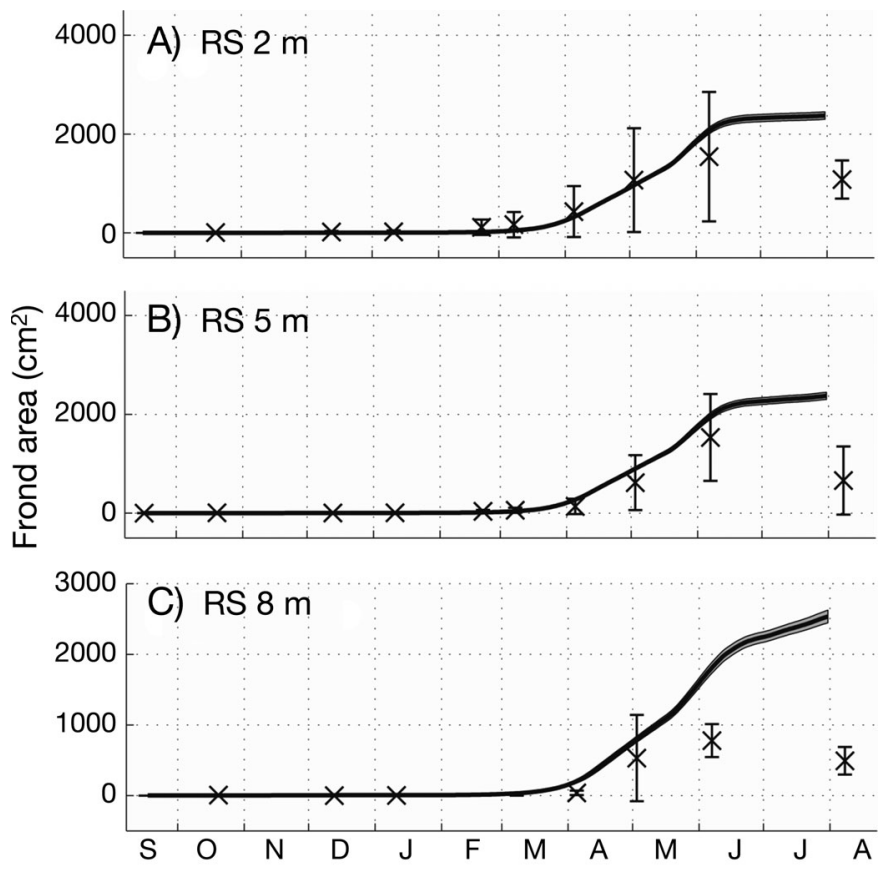

Fig. 9. Saccharina latissima. Average simulated (Simulation $\mathrm{B}_{\text {Aug, } \mathrm{N}}$, continuous lines) and measured (crosses) frond areas $\left(\mathrm{cm}^{2}\right)$ for the August deployment at the reference station (RS) (Fig. 1B) at (A) $2 \mathrm{~m}$, (B) $5 \mathrm{~m}$ and (C) $8 \mathrm{~m}$ depth. The shaded regions and error bars indicate standard deviations of simulated and observed values, respectively 
Table 5. Saccharina latissima. Relative differences $\left[\mathrm{RD}=\left(X_{\text {simulated }}-X_{\text {measured }}\right) / X_{\text {measured }}\right)$ between simulated (Simulation $\mathrm{B}_{\mathrm{Aug}, \mathrm{N}}$, see Table 2) and measured average values for frond areas on the sampling dates in the field experiment for the August deployment. Temporal mean RD and mean absolute RD are also presented. Sample correlation coefficients (r) for the simulated against the measured mean values in October to June are presented in the far right column. FF: fish farm; RS: reference station

\begin{tabular}{|c|c|c|c|c|c|c|c|c|c|c|c|c|}
\hline Station & Depth & Oct & Dec & Jan & Feb & Mar & Apr & May & Jun & Mean RD & Mean of absolute RD & $\mathrm{r}$ \\
\hline \multirow[t]{3}{*}{$\mathrm{FF}$} & 2 & -0.8 & -0.17 & -0.53 & -0.31 & 0.12 & 0.69 & 0.25 & 0.4 & -0.07 & 0.41 & 0.996 \\
\hline & 5 & -0.76 & 0.62 & -0.24 & -0.41 & -0.26 & 0.15 & -0.19 & -0.02 & -0.14 & 0.37 & 0.994 \\
\hline & 8 & -0.81 & 0.42 & 0.3 & - & 0.6 & 1.64 & 6.88 & 1.76 & 1.54 & 1.77 & 0.959 \\
\hline \multirow[t]{3}{*}{ RS } & 2 & -0.79 & -0.74 & -0.71 & -0.83 & -0.72 & -0.25 & -0.10 & 0.34 & -0.48 & 0.56 & 0.978 \\
\hline & 5 & -0.78 & 0.1 & -0.24 & -0.55 & -0.35 & 1.01 & 0.46 & 0.28 & -0.01 & 0.47 & 0.997 \\
\hline & 8 & -0.72 & - & 6.56 & - & - & 4.37 & 0.50 & 1.33 & 2.41 & 2.65 & 0.969 \\
\hline
\end{tabular}

Key figures from Simulations D are presented in Table 6, where we have assumed harvest on 15 June. The total 100 ha kelp farm biomass on 15 June was 17200 and 7460 t FW for Simulations $\mathrm{D}_{\mathrm{Aug}, \mathrm{N}}$ and $\mathrm{D}_{\mathrm{Feb}, \mathrm{N}}$, respectively, compared with a gross accumulated salmon biomass of around $5200 \mathrm{t}$ on this date (Fig. 14A). The gross accumulated salmon biomass (black line in Fig. 14A) was determined by adding the monthly salmon production values to the initial biomass on 1 June 2010, disregarding slaughtered and dead fish.
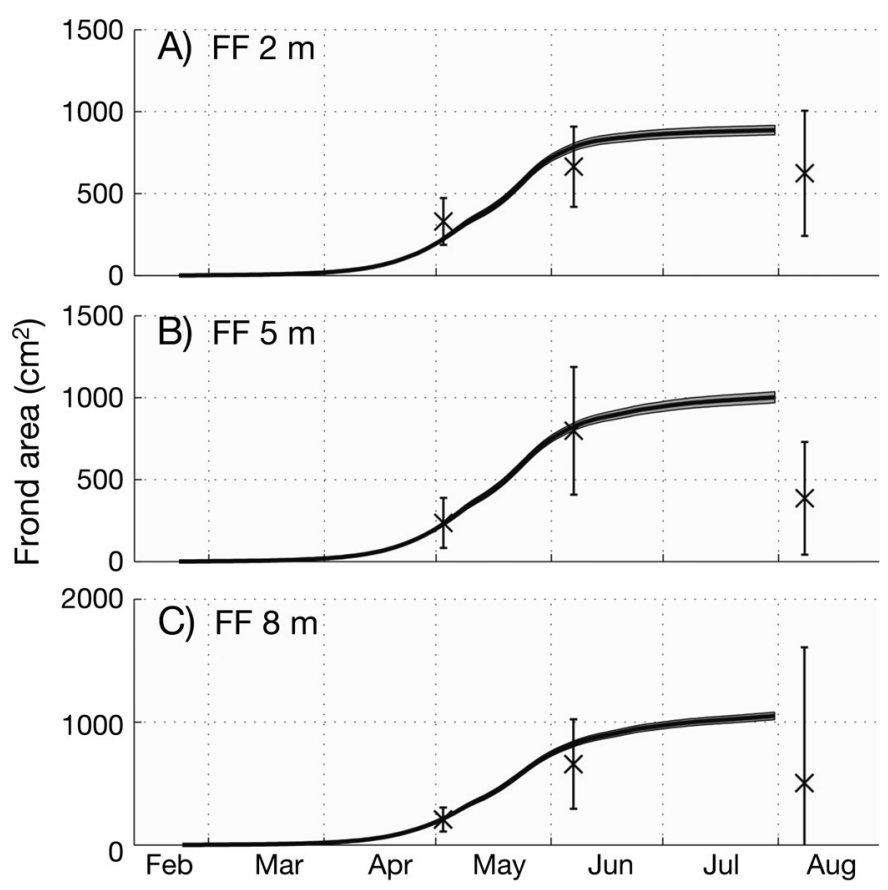

Fig. 10. Saccharina latissima. Average simulated (Simulation $\mathrm{B}_{\mathrm{Feb}, \mathrm{N}}$ continuous lines) and measured (crosses) frond areas $\left(\mathrm{cm}^{2}\right)$ for the February deployment at the fish farm (FF) station (Fig. 1B) at (A) $2 \mathrm{~m}$, (B) $5 \mathrm{~m}$ and (C) $8 \mathrm{~m}$ depth. The shaded regions and error bars indicate standard deviations of simulated and observed values, respectively
FW and DW yields per hectare varied within the 100 ha farm (Table 6, Fig. 15A,B). In Simulation $\mathrm{D}_{\mathrm{Feb}, \mathrm{N}}$ the maximal FW yield per hectare within the farm was $69 \%$ higher than the minimal one (Fig. 15A). The greatest relative increase in biomass (t DW ha ${ }^{-1}$ ) from Simulation $\mathrm{D}_{\mathrm{Feb}}$ to $\mathrm{D}_{\mathrm{Feb}, \mathrm{N}}$ was about $8 \%$ (Fig. 15D). The greatest absolute increases in DW from Simulation $\mathrm{D}_{\mathrm{Feb}}$ to $\mathrm{D}_{\mathrm{Feb}, \mathrm{N}}$ were found closest to the fish farm (Fig. 15C).

The N-uptake of the kelp farm in Simulation $\mathrm{D}_{\text {Aug, } N}$ exceeded the effluent from the fish farm in April and May only (Fig. 14B). The average daily nitrogen uptake per hectare of the kelp farm rarely exceeded $1 \%$ of the salmon farm effluent (Fig. 14B), peaking at about 3 and $1 \%$ in May for Simulations $D_{\text {Aug, N }}$ and $\mathrm{D}_{\mathrm{Feb}, \mathrm{N}}$, respectively. A negative net uptake meant that the amount of nitrogen released to the ambient water masses through frond erosion was greater than the amount taken up. More than $90 \%$ of the total

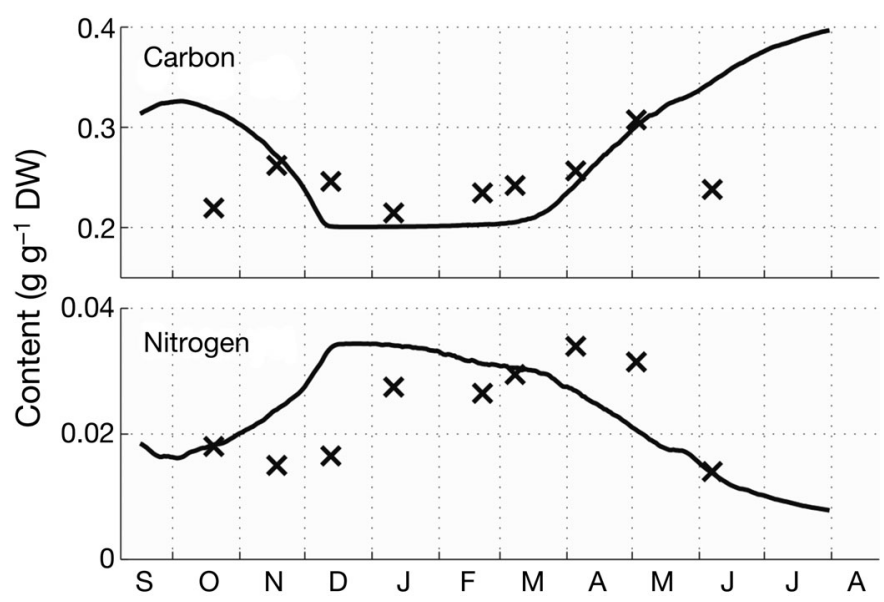

Fig. 11. Saccharina latissima. Simulated (Simulation $B_{\mathrm{Aug}, \mathrm{N}}$ continuous line) and sampled (crosses) carbon and nitrogen content for the plants at the fish farm station at $5 \mathrm{~m}$ depth. DW: dry weight 


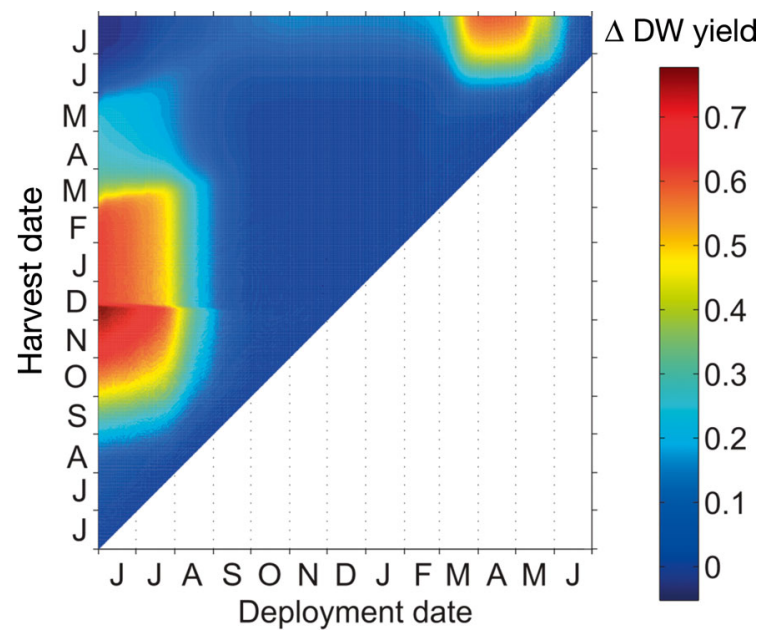

Fig. 12. Saccharina latissima. Relative effect of salmon farm $\mathrm{NH}_{4}{ }^{3}-\mathrm{N}$ on a single $S$. latissima sporophyte (deployed at $5 \mathrm{~m}$ depth), interpreted as a function of deployment and harvest date. Each vertical line represents the development of 1 deployment. Colours indicate the relative difference in dry weight (DW) between Simulation $\mathrm{C}_{\mathrm{N}}$ and $\mathrm{C}$ (see Table 2 for details on simulations)

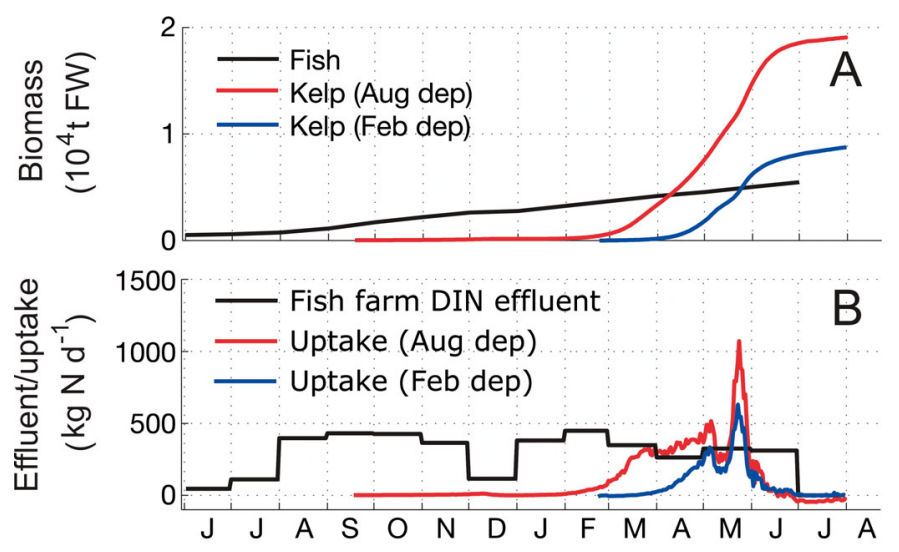

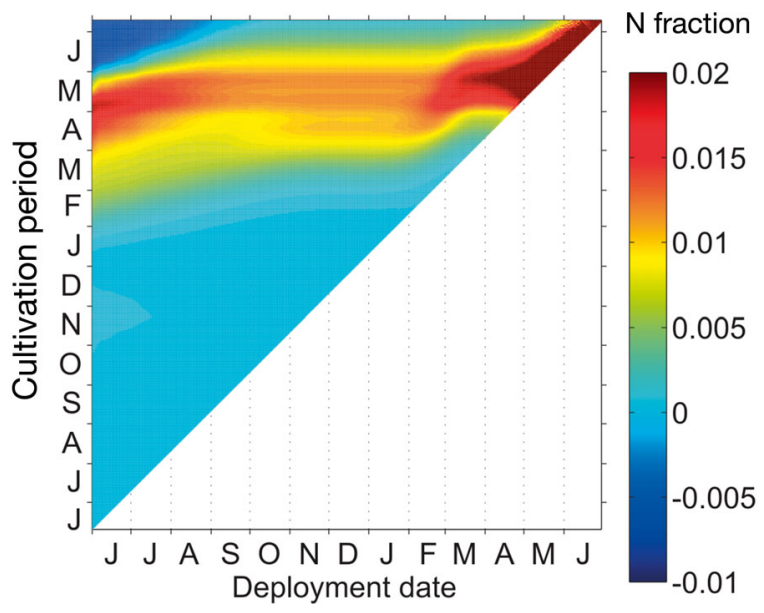

Fig. 13. Saccharina latissima. Nitrogen uptake (30 d running means) expressed as daily fractions of uptake for the entire cultivation period versus deployment dates
Fig. 14. Some results from Simulations $D_{\mathrm{Aug}, \mathrm{N}}$ and $\mathrm{D}_{\mathrm{Feb}, \mathrm{N}}$ (see Table 2 for simulations). (A) Time series of accumulated gross fish biomass produced (black line) and simulated biomass of the 100 ha Saccharina latissima farm $\left(10^{4} \mathrm{t}\right.$ fresh weight [FW]) in Simulations $\mathrm{D}_{\text {Aug, }}(\mathrm{red})$ and $\mathrm{D}_{\mathrm{Feb}, \mathrm{N}}$ (blue). (B) Average mean $\mathrm{NH}_{4}{ }^{+}-\mathrm{N}$ effluent (kg $\mathrm{d}^{-1}$ ) from the fish farm (black line) compared with simulated net uptake $\left(\mathrm{kg} \mathrm{d}^{-1}\right)$ of nitrogen by the entire 100 ha $S$. latissima farm in Simulations $\mathrm{D}_{\mathrm{Aug}, \mathrm{N}}(\mathrm{red})$ and $\mathrm{D}_{\mathrm{Feb}, \mathrm{N}}($ blue)

Table 6. Saccharina latissima. Key figures for simulated production and the nitrogen uptake potential of the hypothetical 100 ha $S$. latissima farm located close to the fish farm at Tristeinen (Figs. 1B \& 15) in Simulations D (see Table 2), with harvest date in all cases on 15 June. Numbers in parentheses are minimum and maximum per hectare values within the 100 ha farm, respectively. FW: fresh weight; DW: dry weight

\begin{tabular}{|c|c|c|c|c|}
\hline Simulation & $\mathrm{D}_{\mathrm{Feb}}$ & $\mathrm{D}_{\mathrm{Feb}, \mathrm{N}}$ & $\mathrm{D}_{\text {Aug }}$ & $\mathrm{D}_{\text {Aug }, N}$ \\
\hline Cultivation period (d) & 115 & 115 & 273 & 273 \\
\hline FW biomass (t ha $\left.{ }^{-1}\right)$ & $70(49,83)$ & $75(53,88)$ & $170(150,180)$ & $172(156,187)$ \\
\hline DW biomass ( $\mathrm{tha}^{-1}$ ) & $10.6(7.6,12.4)$ & $11.2(8.0,12.9)$ & $28.1(25.7,29.7)$ & $28.8(26.5,30.4)$ \\
\hline Dry matter content $(\%)$ & 15.1 & 15.0 & 16.5 & 16.7 \\
\hline Average net $\mathrm{N}$ uptake $\left(\mathrm{kg} \mathrm{ha}^{-1}\right)$ & 138 & 151 & 336 & 355 \\
\hline Average daily net $\mathrm{N}$ uptake $\left(\mathrm{kg} \mathrm{ha}^{-1}\right)$ & 1.2 & 1.3 & 1.2 & 1.3 \\
\hline Average net production $\left(\mathrm{g} \mathrm{C} \mathrm{m}^{-2}\right)$ & 370 & 380 & 1030 & 1050 \\
\hline Average daily net production $\left(\mathrm{g} \mathrm{C} \mathrm{m}^{-2}\right)$ & 3.17 & 3.30 & 3.77 & 3.83 \\
\hline Total $\mathrm{NH}_{4}-\mathrm{N}$ effluent in kelp cultivation period (t) & - & 37.0 & - & 103.6 \\
\hline $\begin{array}{l}\text { Percentage of total effluent in kelp cultivation } \\
\text { period taken up ha }\end{array}$ & - & 0.41 & - & 0.34 \\
\hline
\end{tabular}



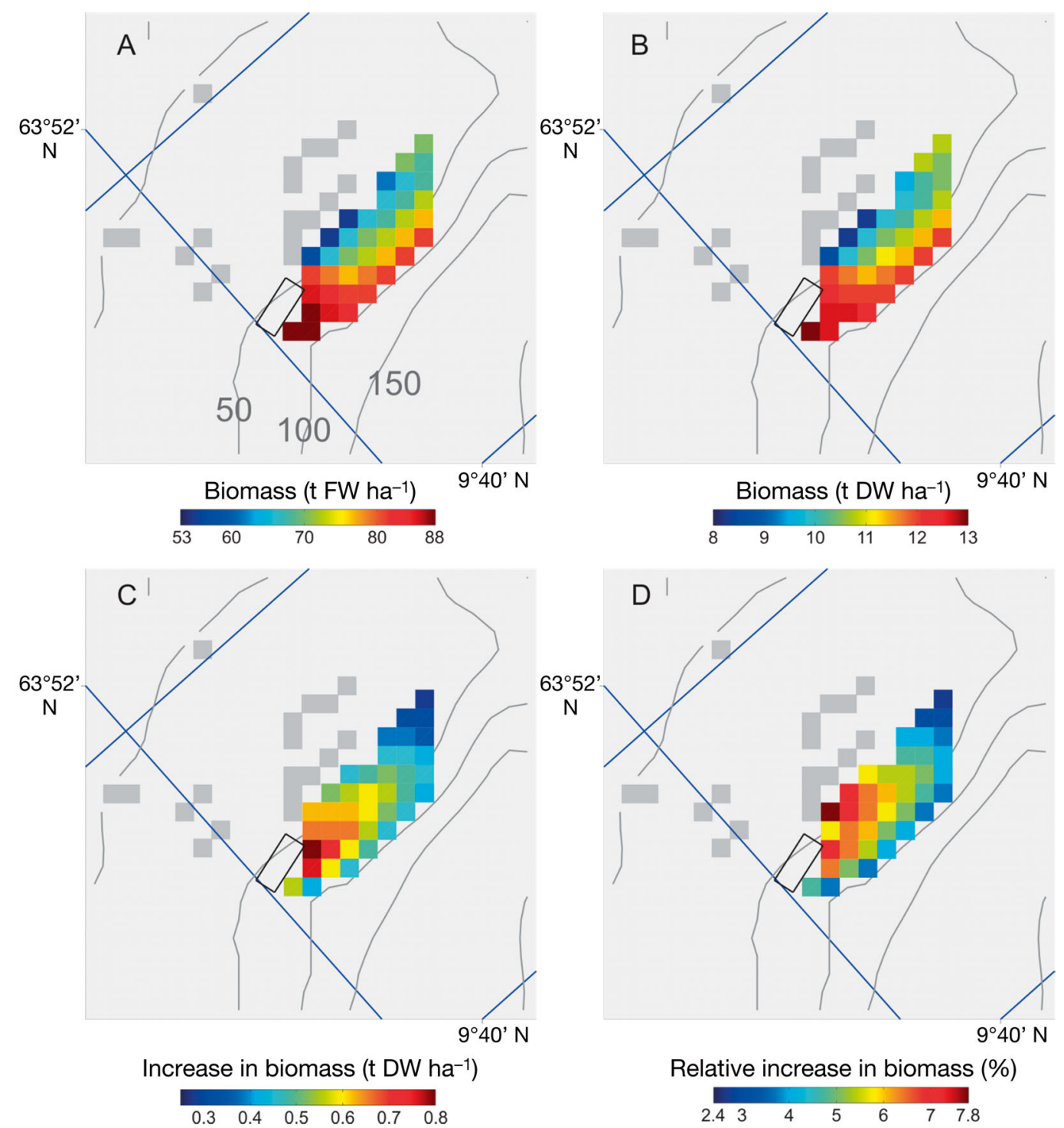

Fig. 15. Saccharina latissima. Simulation of a 100 ha S. latissima farm (coloured squares) adjacent to the fish farm, the mooring frame of which is outlined as a black rectangle. Horizontal grid resolution is $160 \mathrm{~m}$; dimensions of the mooring frame are $200 \times$ $500 \mathrm{~m}$. Grey curves are 50, 100 and $150 \mathrm{~m}$ isobaths. Deployment on 21 February, harvest on 15 June. (A) S. latissima fresh weight (FW) biomass, Simulation $\mathrm{D}_{\mathrm{Feb}, \mathrm{N}}$ (B) S. latissima dry weight (DW) biomass, Simulation $\mathrm{D}_{\mathrm{Feb}, \mathrm{N}}$. (C) Increase in $S$. latissima DW biomass from Simulation $\mathrm{D}_{\mathrm{Feb}}$ to $\mathrm{D}_{\mathrm{Feb}, \mathrm{N}}$. (D) Relative increase in S. latissima DW biomass from Simulation $\mathrm{D}_{\mathrm{Feb}}$ to $\mathrm{D}_{\mathrm{Feb}, \mathrm{N}}(\%)$. Dark grey regions indicate land. See Table 2 for details on simulations

nitrogen uptake by the 100 ha Saccharina latissima cultures in Simulation $\mathrm{D}_{\text {Aug, } \mathrm{N}}$ was assimilated in March, April and May (Figs. 14B \& 16). The decrease in the water DIN concentration due to nitrogen uptake by the 100 ha $S$. latissima farm was confined mainly to the farm itself, with an average decrease of about $1 \mathrm{mmol} \mathrm{m}^{-3}$ in May (Fig. 16).

There were only minor differences in dry matter content and net production at harvest $\left(\mathrm{g} \mathrm{C} \mathrm{m}^{-2}\right)$ between Simulations $D_{\mathrm{Feb}}$ and $\mathrm{D}_{\mathrm{Feb}, \mathrm{N}}$ and between Simulations $\mathrm{D}_{\mathrm{Aug}}$ and $\mathrm{D}_{\mathrm{Aug}, \mathrm{N}}$ (Table 6).

\section{Light shading (Simulations E)}

The values in Table 6 were based on simulations without light shading effects from the kelp plants, but including the effects of kelp uptake on the nutrient concentration. Data on biomass on 15 June from Simulations E, including the effects of shading, are presented in Fig. 17A-D, as well as linearly extrapolated yields based on the average simulated biomass for 1 single $5 \mathrm{~m}$ long vertical rope. With the highest rope density, linear extrapolation yielded a biomass 

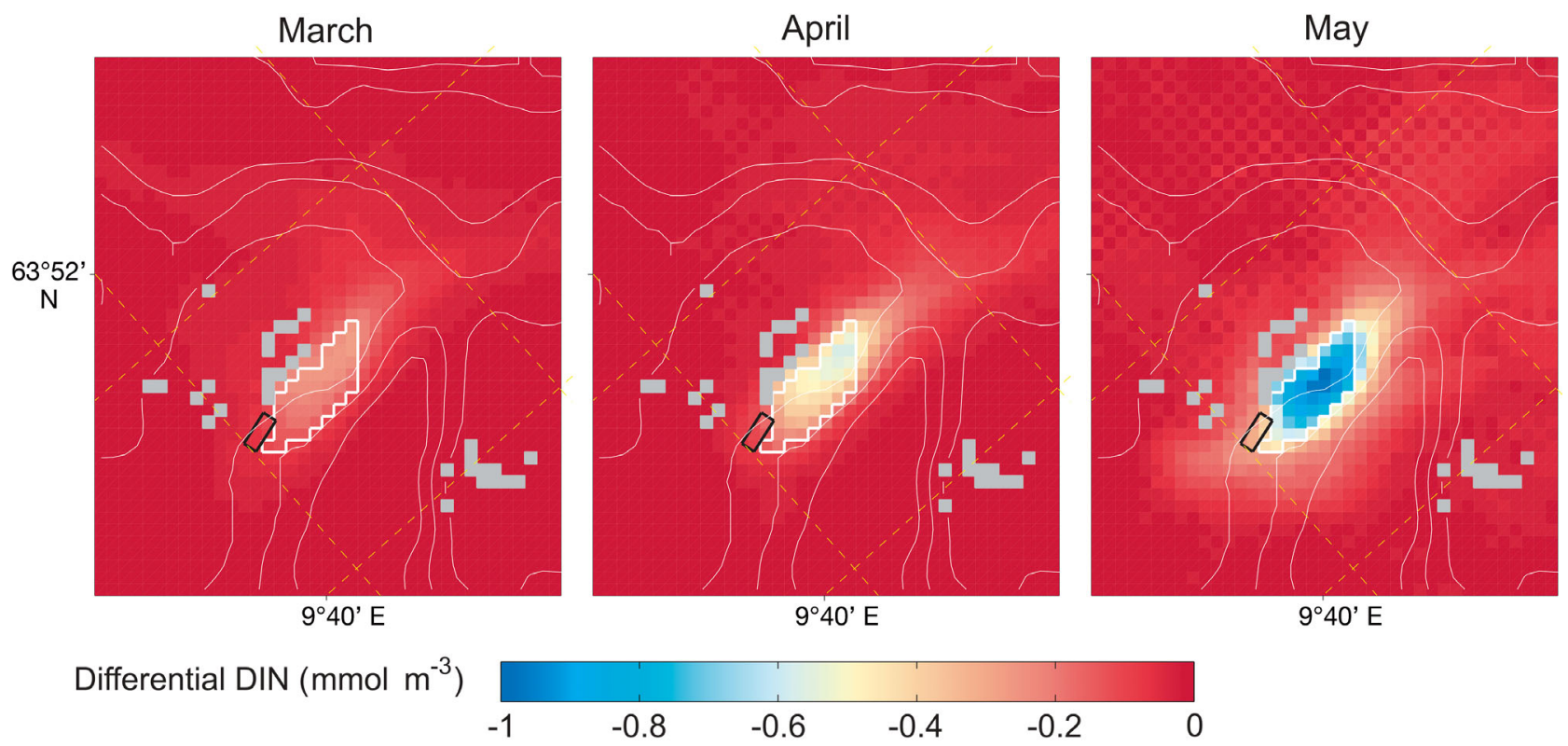

Fig. 16. Simulated differences in total dissolved inorganic nitrogen (DIN $=\mathrm{NO}_{3}{ }^{-}+\mathrm{NH}_{4}{ }^{+}$) concentrations between Simulations

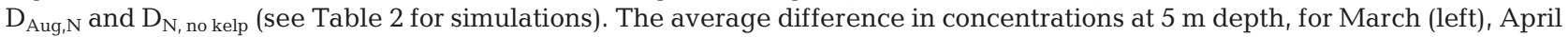
(middle) and May (right) are shown. The fish farm is indicated by the black rectangle, while the white polygon outlines the hypothetical 100 ha Saccharina latissima farm
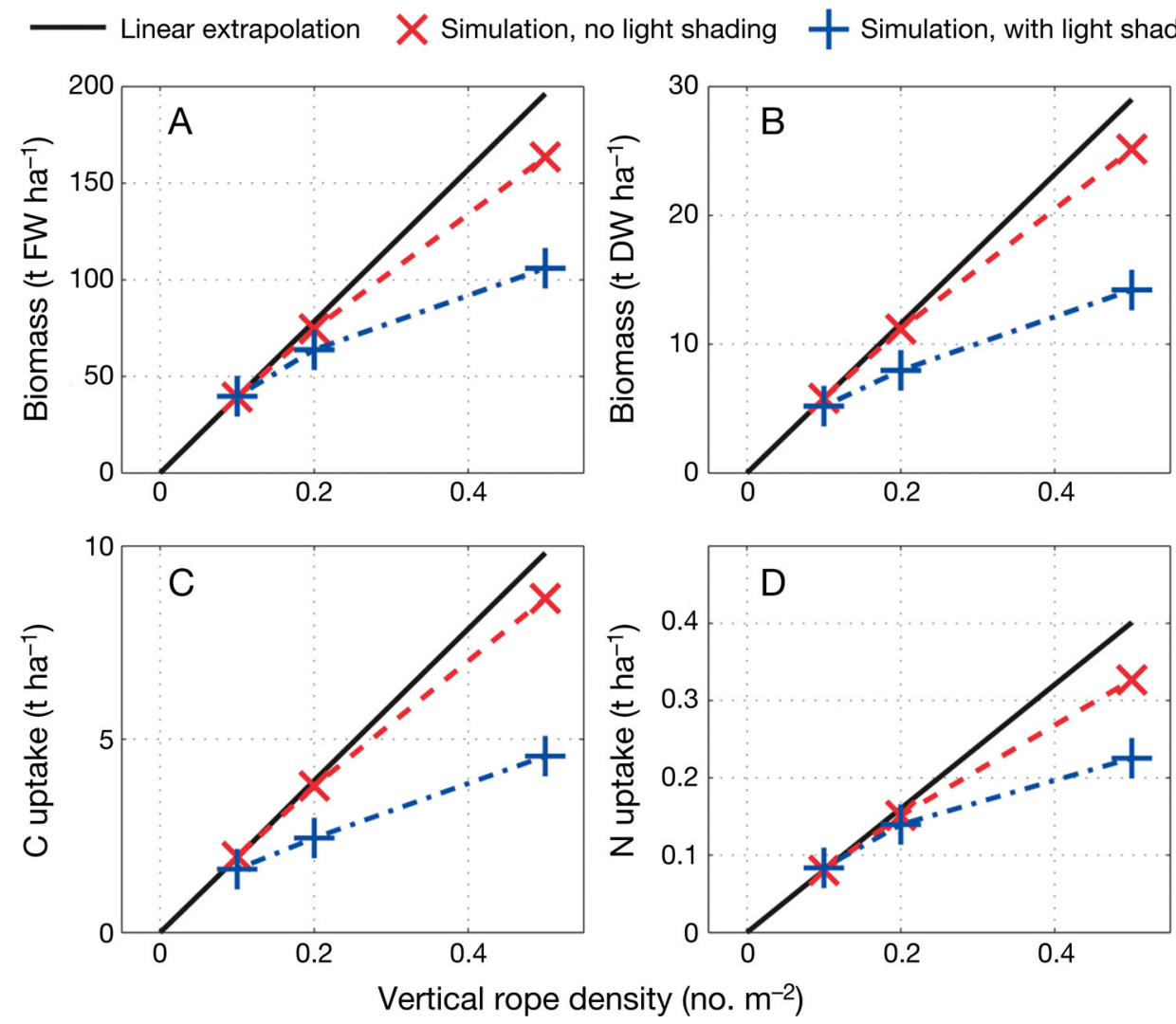

Fig. 17. Saccharina latissima. Comparisons of $(\mathrm{A}, \mathrm{B})$ biomass yields and $(\mathrm{C})$ carbon and (D) nitrogen uptake estimated in 3 ways: (1) linear extrapolation of simulated values for a single $5 \mathrm{~m}$ long vertical rope (continuous black lines), (2) simulations with nutrient uptake by the kelp but no light shading (red crosses) and (3) simulations with nutrient uptake and light shading by the kelp (blue plus signs). In all cases the biomass was assumed to be harvested on 15 June, with deployment on 21 February. 
of $196 \mathrm{t} \mathrm{FW} \mathrm{ha}^{-1}$, compared to a biomass of $106 \mathrm{t} \mathrm{FW}$ $\mathrm{ha}^{-1}$ when the combined effects of light shading and nutrient consumption were taken into account (Fig. 17A). For DWs the figures were 29 versus $14 \mathrm{t}$ ha $^{-1}$ (Fig. 17B). As one would expect, light shading affected carbon uptake more than nitrogen uptake (Fig. 17C,D).

\section{DISCUSSION}

\section{Mesocosm experiment and model adjustment}

The Saccharina latissima model captured important trends in frond area growth and nitrogen and carbon dynamics of the plants in the basin (Fig. 4, Table 4). Towards the end of Simulation A the model did very well, except for a notable difference between simulated and measured $\mathrm{N}$ content in March (Table 4). As the basin $\mathrm{NO}_{3}{ }^{-}$concentration decreased, so did the relative $\mathrm{N}$ content of the $S$. latissima fronds (Fig. 4B,D). The main cause of the decrease in tissue $\mathrm{N}$ concentration was a combination of dilution by growth and an increase in relative $\mathrm{C}$ content. The model and the simulations corroborate this.

An in-basin phytoplankton bloom caused nutrient depletion from February to March (Fig. 4B). The conditions in the basin emulated the conditions along the Norwegian coast, with a phytoplankton spring bloom starting with the onset of sufficient light intensities and stratified water masses (Rey et al. 2007).

The new subdivision of respiration into basal respiration and respiration (or carbon consumption) related to growth and uptake gave a much better fit with the mesocosm data than the original respiration function, which was dependent on temperature only.

\section{Partial model validation}

The good correlations between simulated and measured average frond areas (Table 5) indicate that the seasonal growth patterns of the Saccharina latissima plants up to and including the June sampling were well resolved by the model at 2 and $5 \mathrm{~m}$ depths in Simulation $\mathrm{B}_{\mathrm{Aug}, \mathrm{N}}$ and at all depths in Simulation $\mathrm{B}_{\mathrm{Feb}, \mathrm{N}}$ (Figs. 8, 9 \& 10).

The model generally over-estimated the frond area at $8 \mathrm{~m}$ depth at the FF and RS stations in Simulation $\mathrm{B}_{\text {Aug,N }}$ (Figs. 8C \& 9C, Table 5). There are 2 probable reasons for this. First, the model parameters were adjusted against growth data down to $3 \mathrm{~m}$ depth, so that the parameters perhaps did not permit an adequate photosynthetic response to reduced light availability at $8 \mathrm{~m}$. Second, we did not take into consideration light shading among the plants in the validation simulations, which would have reduced light availability for the plants at $8 \mathrm{~m}$ depth. This fits well with the fact that the February plants grew more evenly at all depths, since irradiance levels were higher due to the season, while the February plants at 2 and $5 \mathrm{~m}$ depths would not shade the $8 \mathrm{~m}$ plants as much as the corresponding August plants in February to June. Hence, the $8 \mathrm{~m}$ plants probably kept up with the 2 and $5 \mathrm{~m}$ plants, being less photosynthetically inhibited.

The model mechanics for frond erosion are in place (Fig. 8), but the frond area was over-estimated by the end of July in all simulations. One explanation for this is that the model was adjusted against a data set where the plants showed little or no signs of frond erosion. The model presently uses size as the driver of frond erosion (Broch \& Slagstad 2012). Temperature and water current speed could have been included as important environmental variables here. Epiphyte infestation is also of importance (Andersen et al. 2011, Forbord et al. 2012, Park \& Hwang 2012).

The model resolved the individual variation in frond area for the August deployment (Simulation $\left.\mathrm{B}_{\text {Aug, }}\right)$ at the FF station, expressed as the standard deviation (SD), to some degree (Fig. 8, Table 2). Because the same parameters were used for all individuals, only the initial conditions contributed to differences in later values of the state variables. Hence very good resolution of the variation on the individual level should not be expected. There was some variation on the individual level in the results of Simulation $\mathrm{B}_{\mathrm{Aug}, \mathrm{N}}$ for the RS station and Simulation $\mathrm{B}_{\mathrm{Feb}, \mathrm{N}}$ for the FF station (Figs. 9 \& 10), due to the initial variation in the reserve levels only (Table 2). The variation in individual frond area $(A)$ was small, however, reconfirming that this state variable is not sensitive to initial values of the other 2 states (the reserves $N$ and $C_{\text {i }}$ Broch \& Slagstad 2012).

The calculation of the measured frond areas from length and width was rough, but had the advantage of simplicity, and is reminiscent of a method applied by Peteiro \& Freire (2012). Frond areas were not actually measured. Changes in growth patterns, and hence morphology, over time (Sjøtun 1993) would have changed the constant 0.75 (cf. Eq. 1 in 'Field data and IMTA experiment').

The simulated values for carbon and nitrogen content matched the measured ones to some degree (Fig. 11). Displacement occurred along the time axis of the simulated values relative to the measured ones. The decrease in carbon content from the sam- 
pling in May to the one in June seems counter-intuitive. The light intensity and water temperatures and hence photosynthetic activity should have increased, while the relative growth rate should have decreased due to nutrient depletion. The sample size was small $(\mathrm{n}=2)$. The match between simulated and measured values for relative nitrogen content in spring (February to May) is good enough to ensure that the simulated rates of nitrogen uptake per unit biomass in this period are realistic.

\section{SINMOD environmental data}

Simulated summer and spring values for $\mathrm{NO}_{3}{ }^{-}$concentrations from Simulation $\mathrm{B}_{\mathrm{Aug}, \mathrm{N}}$ were in agreement with observations (Fig. 6B). The spring bloom resulted in nutrient depletion in April, both in the model and observations. The concentration stayed low during summer, began to increase in October, and continued to increase during the winter due to winter mixing and light-limited phytoplankton growth (no consumption). This is in agreement with present knowledge of the biochemical cycle of Norwegian coastal waters (Rey et al. 2007). In light of this, the observed persistently low nutrient levels from November to March are difficult to interpret. This is not a critical issue here, as the kelp was not nutrient limited in this period.

$\mathrm{NH}_{4}{ }^{+}-\mathrm{N}$ is generated by degradation processes of organic material in deeper water and in the sediments, released from the fish farm and in freshwater runoff from land in the present simulations. The events of elevated concentrations 1 to 2 times a month (Fig. 6B) were therefore most likely signals of deeper water reaching the surface caused by upwelling or eddy transport. The frequency of such events cannot be captured by monthly samples and thus could not be verified by the observations. The simulated and measured values for $\mathrm{NH}_{4}{ }^{+}-\mathrm{N}$ concentrations were slightly lower than previously reported values by, e.g., Sanderson et al. (2008), but the water current speeds reported in their study were lower than the ones in the present study. There may be an influence of numerical dilution on the $\mathrm{NH}_{4}{ }^{+}-\mathrm{N}$ concentration by 'releasing' directly into a grid cell of, say, $160 \times 160 \times 1 \mathrm{~m}$. However, such dilution effects are mainly local (Broch et al. 2013). Overall, the model system resolved DIN concentrations fairly well.

The $160 \mathrm{~m}$ model captured the general trend in the current measurements. The current speeds at the SWB location (Fig. 1B) were fairly low, and the meas- urements contained some noise. Perfect agreement between model and observations cannot be expected in such a comparison, because the current sensor detected variations in currents on a finer scale than a $160 \mathrm{~m}$ model can resolve. Ideally, we would have wished for current measurements at the fish farm itself and at the reference station, for a significant time period during the field trial. The data and comparison have been included to corroborate the model's ability to simulate the spreading and dilution of the fish farm DIN effluent.

\section{Simulation experiments and implications for IMTA}

Estimates of the large-scale nitrogen uptake and biomass production capacity of macroalgae in IMTA have been given in a number of recent papers. Abreu et al. (2009) found that a 100 ha Gracilaria chilensis farm would be needed to fully bioremediate the DIN from a fish farm producing $1000 \mathrm{t}$ of salmon. According to Sanderson et al. (2012), a 1 ha Saccharina latissima culture (over 2 growth seasons) might remove the equivalent of 5.3 to $10 \%$ of the DIN from a $500 \mathrm{t}$ salmon production in a 2 yr production cycle. The largest Norwegian salmon farms are already producing $\sim 12000 \mathrm{t}$ per production cycle, and are aiming towards increasing and intensifying production.

The estimates just mentioned were based on linear extrapolation of the results of small-scale experiments. We have seen (Fig. 17A-D) that upscaling in this way over-estimates production, even without taking into account possible current reduction. The reason for this is that the coupled hydrodynamicecological-kelp model system responds non-linearly to increases in stocking density and nutrient consumption, as one would expect in an actual aquaculture system (Troell et al. 2009).

Our results that the main period of nutrient uptake and growth of Saccharina latissima plants is spring (Figs. 13 \& 14) fit well with previous experimental studies (Brinkhuis et al. 1984, Sjøtun 1993, Andersen et al. 2011, Forbord et al. 2012). The period of a relatively high nitrogen assimilation capacity remained virtually the same, regardless of the time of deployment (Fig. 13). Growth rates in the kelp model were adjusted by a photoperiodic forcing function, taking into account the rate of change of the day length (Broch \& Slagstad 2012), and growth was most heavily forced during the spring (increasing growth) and autumn (decreasing growth) equinoxes. Thus, these results are not surprising, but they do have implications for IMTA and cultivation strategies. 
The monthly DIN effluent from the ACE fish farm was fairly constant from August 2010 to June 2011 (except in December). Our results indicate that a constant removal of $\mathrm{NH}_{4}{ }^{+}-\mathrm{N}$ from fish farms by Saccharina latissima cultures may be difficult to achieve because a major part ( $90 \%$ ) of the $\mathrm{N}$ is taken up during spring (March to May) only. For $100 \%$ removal, one will have to remove several times the effluent for shorter periods of time, mainly during the annual phytoplankton spring bloom (February to May; Fig. 14B). Thus, there is a seasonal 'mismatch' between release and uptake of DIN in the simulated system, and it seems to be hard to find a good balance between salmon and kelp biomass (Fig. 14A). For large-scale operations, further consequences of this must be evaluated.

A possible harvesting practice that would avoid removing more nitrogen than is released from the fish farm would be to harvest continuously from the time when the uptake exceeds the effluent, perhaps using models to estimate the daily nitrogen removal capacity. Year-round deployment of Saccharina latissima cultures is possible (Forbord et al. 2012), but it is a challenge to maintain large plants throughout the summer (Forbord et al. 2012). Harvesting part of the grown out kelp frond may also be a possibility. If removal of a fixed percentage of the DIN effluent is required, changing the algal crop with the seasons is an option (Troell et al. 2009). Reducing salmon production is an obvious approach.

It should be noted that there has been no call for total bioremediation, and, assuming a reasonable rate of water exchange, the dissolved nutrients from salmon farming may possibly contribute positively to the Norwegian coastal ecosystem, which is generally nutrient limited in summer (Rey et al. 2007).

The conspicuous peak in nitrogen uptake with an ensuing increase in growth in late May (Fig. 14B) was due to a sudden increase in the simulated concentrations of $\mathrm{NO}_{3}{ }^{-}$(Fig. 6B) not related to any anthropogenic effects. This indicates a high potential for biomass increase even late in the growth season for locations with natural upwelling, and that the effects of natural upwelling may prove to be greater than those of IMTA. These matters should be further investigated.

For large-scale farm simulations, the harvest date (15 June) was chosen, because in field experiments Saccharina latissima plants seem to start deteriorating in June (Forbord et al. 2012).

The net production of $>1000 \mathrm{~g} \mathrm{C} \mathrm{m}^{-2}$ in Simulation $\mathrm{D}_{\text {Aug }}$ (Table 6) is high, but not unrealistic (Krumhansl \& Scheibling 2012). By comparison, production of
Laminaria hyperborea has been reported to be as high as $3000 \mathrm{~g} \mathrm{C} \mathrm{m}^{-2}$ (Abdullah \& Fredriksen 2004).

We have not taken into consideration the effects of the fish and kelp farms themselves on the water currents, which may reduce the fluxes of nutrients within the IMTA system (Grant \& Bacher 2001, Plew 2011, Stevens \& Petersen 2011). Neither have we considered small-scale reduction in DIN concentrations around single kelp ropes due to crowding of the plants. Hence, production and nitrogen uptake in Simulations D were over-estimated in these respects.

Spatial variation in biomass yields has implications for the planning process of kelp aquaculture. The variation in simulated yields within the 100 ha farm was due to natural spatial variations in nutrient concentrations, current speeds and water clarity. Furthermore, the largest yields were close to the fish farm. The main current direction was NNE from the farm, which means that the plots closest to the farm had the benefit of higher nutrient concentrations, while nutrients were gradually taken up further into the 100 ha farm (Fig. 16). Detritus due to eroded frond tissue might also have an effect here (included in the model), but not until late in the growth period.

Our values for increased Saccharina latissima DW biomass due to fertilization by the salmon farm (an average increase of $\sim 6 \%$ for the February deployment; Table 6) seem low compared with the figure of $27 \%$ reported by Sanderson et al. (2012). However, we have seen that simulated increases in DW by fish farm fertilization may be higher than $70 \%$, depending on the length of the growth season and the date of deployment (Fig. 12).

We have focused on the area requirements of kelp aquaculture because space for further aquaculture leases in the coastal zone is generally limited for a number of factors (Troell et al. 2009, Hersoug \& Johnsen 2012).

Dynamical models have been used to study open IMTA systems for at least 20 yr. Several models have included bivalves (e.g. Ren \& Ross 2005, LauzonGuay et al. 2006, Ferreira et al. 2012) and kelps (Petrell et al. 1993, Duarte et al. 2003, Trancoso et al. 2005, Shi et al. 2011, Ren et al. 2012). The present study is new in the sense that we used fully coupled and nested 3D models with realistic weather data and hydrodynamic boundary conditions, as well as detailed nutrient loading rates and salmon biomass. This was necessary as we focused on a single site case in a genuinely open-water system, a case which has been somewhat neglected in the literature.

The present model system is a flexible tool that can be set up for any location provided good topographi- 
cal data are available. Important aspects of the development of the Saccharina latissima fronds on the individual level were resolved. However, the largescale FW and DW biomass estimates have not been validated, and the model cannot at present be used to give precise upper bounds for the $S$. latissima cultivation potential at a given location. The inclusion of detailed interactions between individual plants, mortality, local nutrient limitation, improved growth of the early sporophyte stage, current effects on frond morphology and biomass, and current reduction features would all contribute to improving the overall model. This requires detailed experimental data currently not available.

It is beyond the scope of this article to touch upon the use of filter feeders like blue mussel Mytilus edulis (Handå et al. 2012, Lander et al. 2012) in concert with extractive species in IMTA. Nor have we considered the effects and fate of detritus from eroded kelp fronds, which may provide a significant contribution (Krumhansl \& Scheibling 2012). The filter-feeding component may turn out to be more relevant from a bioremediation perspective (Carroll et al. 2003).

The last years have seen a renewed interest in the uses of macroalgal biomass in the western hemisphere (Kraan 2010, Holdt \& Kraan 2011, Wargacki et al. 2012), in particular for bioenergy purposes, which require vast amounts of biomass (Hughes et al. 2012) that can only be supplied through cultivation. The cultivation costs will have to be lowered if bioenergy from kelp biomass is to compete with fossil fuels at present (Hughes et al. 2012). IMTA might lower the production costs, increase the biomass (present study), and may even be economically viable (Petrell \& Alie 1996). The labour costs of tending kelp cultures is a critical factor considering the high value of, for example, the Norwegian salmon production at NOK $3 \times 10^{10}$ in 2010 (Statistics Norway 2012, www.ssb.no).

\section{CONCLUSIONS}

The present results suggest a possible cultivation of $170 \mathrm{t} \mathrm{FW} \mathrm{ha}^{-1}$ of Saccharina latissima from August to June, with a net removal of about $0.34 \%$ of the $\mathrm{NH}_{4}{ }^{+}-\mathrm{N}$ released from a fish farm producing $5000 \mathrm{t}$ salmon in a production cycle. A seaweed installation of the same size as the area requirements of the fish farm (about 30 ha including cages, feed barge and traffic routes) will thus yield comparable seaweed and fish biomass (FW), with a possible $10 \%$ removal of the released DIN. Accordingly, the use of seaweed in IMTA with salmon for removal of part of the dissolved nutrients seems promising, whereas large areas of $S$. latissima cultures are needed to take up the total DIN effluent from a $5000 \mathrm{t}$ salmon production. The results also indicate a seasonal mismatch between fish farm effluents and uptake rates in $S$. latissima, suggesting that additional extractive species with complementary uptake rates should be included for optimization of IMTA. Therefore, and due to limitations in space available for future aquaculture leases in the coastal zone, a full bioremediation of Norwegian aquaculture using $S$. latissima is unrealistic.

Acknowledgements. This research was funded by the Research Council of Norway (RCN) through Project No. 199391/I10 (Macrobiomass). The mesocosm growth experiment was carried out through the RCN Project No. 173527 (Integrate, 2007 to 2011). Additional support came from the RCN through Project No. 216201/E40 (Exploit). We also thank NOTUR and the HPC center at the University of Tromsø for computational and human resources. Thanks to everyone at ACE for information on monthly fish biomass and feed usage at the farm at Tristeinen, and to Gunnar Senneset (SINTEF) and Finn Viktor Willumsen (CEO at ACE) for providing current data. Trond Rosten (SINTEF) provided some useful information. Four anonymous reviewers contributed to improving the manuscript.

\section{LITERATURE CITED}

Abdullah MI, Fredriksen S (2004) Production, respiration and exudation of dissolved organic matter by the kelp Laminaria hyperborea along the west coast of Norway. J Mar Biol Assoc UK 84:887-894

Abreu H, Varela DA, Henríquez L, Villaroel A, Yarish C, Sousa-Pinto I, Buschmann AH (2009) Traditional vs. integrated multi-trophic aquaculture of Gracilaria chilensis C. J. Bird, J. McLachlan \& E. C. Oliveira: productivity and physiological performance. Aquaculture 293: 211-220

> Andersen GS, Steen H, Christie H, Fredriksen S, Moy FE (2011) Seasonal patterns of sporophyte growth, fertility, fouling, and mortality of Saccharina latissima in Skagerrak, Norway: implications for Forest Recovery. J Mar Biol 2011:690375

Anon (2011) LOfoten andVEsterålen CURents (LOVECUR). Comparison of hindcasts with measurements, Revision 2. Forristall Ocean Engineering, Camden, ME

Bolton JJ, Lüning K (1982) Optimal growth and maximal survival temperatures of Atlantic Laminaria species (Phaeophyta) in culture. Mar Biol 66:89-94

Brinkhuis BH, Mariani EC, Breda VA, Brady-Campbell MM (1984) Cultivation of Laminaria saccharina in the New York Marine Biomass Program. Hydrobiologia 116/177: 266-271

Broch OJ, Slagstad D (2012) Modelling seasonal growth and composition of the kelp Saccharina latissima. J Appl Phycol 24:759-776 
Broch OJ, Slagstad D, Smit M (2013) Modelling produced water dispersion and its direct toxic effects on the production and biomass of the marine copepod Calanus finmarchicus. Mar Environ Res 84:84-95

> Carroll ML, Cochrane S, Fieler R, Velvin R, White P (2003) Organic enrichment of sediments from salmon farming in Norway: environmental factors, management practices, and monitoring techniques. Aquaculture 226: 165-180

> Chopin T, Buschmann AH, Halling C, Troell M and others (2001) Integrating seaweeds into marine aquaculture systems: a key toward sustainability. J Phycol 37: 975-986

> Cloern JE (2001) Our evolving conceptual model of the coastal eutrophication problem. Mar Ecol Prog Ser 210: 223-253

> Dee DP, Uppala SM, Simmons AJ, Berrisford P and others (2011) The ERA-Interim reanalysis: configuration and performance of the data assimilation system. Q J R Meteorol Soc 137:553-597

> Duarte P, Meneses R, Hawkins AJS, Zhu M, Fang J, Grant J (2003) Mathematical modeling to assess the carrying capacity for multi-species culture within coastal waters. Ecol Modell 168:109-143

Ellingsen IH, Slagstad D, Sundfjord A (2009) Modification of water masses in the Barents Sea and its coupling to ice dynamics: a model study. Ocean Dyn 59:1095-1108

FAO (Food and Agriculture Organization) (2012) The state of the world fisheries and aquaculture 2012. FAO Fisheries and Aquaculture Department, FAO of the United Nations, Rome

> Ferreira JG, Saurel C, Ferreira JM (2012) Cultivation of gilthead bream in monoculture and integrated multi-trophic aquaculture. Analysis of production and environmental effects by means of the FARM model. Aquaculture 358-359:23-24

- Forbord S, Skjermo J, Arff J, Handå A, Reitan KI, Bjerregaard R, Lüning K (2012) Development of Saccharina latissima (Phaeophyceae) kelp hatcheries with yearround production of zoospores and juvenile sporophytes on culture ropes for kelp. J Appl Phycol 24:393-399

Grant J, Bacher C (2001) A numerical model of flow modification induced by suspended aquaculture in a Chinese Bay. Can J Fish Aquat Sci 58:1003-1011

Grasshoff K, Erhardt M, Kemling K (1983) Methods of seawater analysis. Verlag Chemie, Weinheim

> Handå AH, Min H, Wang X, Broch OJ, Reitan KI, Reinertsen $\mathrm{H}$, Olsen Y (2012) Incorporation of fish feed and growth of blue mussel (Mytilus edulis) in close proximity to salmon (Salmo salar) aquaculture: implications for integrated multi-trophic aquaculture in Norwegian coastal waters. Aquaculture 356-357:328-341

Hersoug B, Johnsen JP (2012) Kampen om plass på kysten (The struggle for space along the coast). Universitetsforlaget, Oslo (in Norwegian)

> Holdt SL, Kraan S (2011) Bioactive compounds in seaweed: functional food applications and legislation. J Appl Phycol 23:543-597

Hughes AD, Kelly MS, Black KD, Stanley MS (2012) Biogas from macroalgae: Is it time to revisit the idea? Biotechnol Biofuels 5:86

Kerouel R, Aminot A (1997) Fluorometric determination of ammonia in sea and estuarine waters by direct segmented flow analysis. Mar Chem 57:265-274

Kooijman SALM (2000) Dynamic energy and mass budgets in biological systems, 2nd edn. Cambridge University Press, Cambridge

Kraan S (2010) Mass-cultivation of carbohydrate rich macroalgae, a possible solution for sustainable biofuel production. Mitig Adapt Strategies Glob Change 2010:1-20

Krumhansl KA, Scheibling RE (2012) Production and fate of kelp detritus. Mar Ecol Prog Ser 467:281-301

Lander TR, Robinson SMC, Macdonald BA, Martin JD (2012) Enhanced growth rates and condition index of blue mussels (Mutilus edulis) held at integrated multitrophic aquaculture sites in the Bay of Fundy. J Shellfish Res 31:997-1007

> Lauzon-Guay JS, Barbeau MA, Watmough J, Hamilton DJ (2006) Model for growth and survival of mussels Mytilus edulis reared in Prince Edward Island, Canada. Mar Ecol Prog Ser 323:171-183

Lobban CS, Harrison PJ (1994) Seaweed ecology and physiology. Cambridge University Press, Cambridge

Olsen Y (2011) Resources for fish feed in future mariculture. Aquacult Environ Interact 1:187-200

Oppedal F, Vågseth F, Dempster T, Juell JE, Johansson D (2011) Fluctuating sea-cage environments modify the effects of stocking densities on production and welfare parameters of Atlantic salmon (Salmo salar L.). Aquaculture 315:361-368

Park CS, Hwang EK (2012) Seasonality of epiphytic development of the hydroid Obelia geniculate on cultivated Saccharina japonica (Laminariaceae, Phaeophyta) in Korea. J Appl Phycol 24:433-439

Peteiro C, Freire O (2012) Outplanting time and methodologies related to mariculture of the edible kelp Undaria pinnatifida in the Atlantic coast of Spain. J Appl Phycol 24:1361-1372

Petrell RJ, Alie SY (1996) Integrated cultivation of salmonids and seaweeds in open systems. Hydrobiologia 326/327: 67-73

Petrell RJ, Tabrizi KM, Harrison PJ, Druehl LD (1993) Mathematical model of Larminaria production near a British Columbian salmon sea cage farm. J Appl Phycol 5:1-4

> Plew DR (2011) Shellfish farm-induced changes to tidal circulation in an embayment, and implications for seston depletion. Aquacult Environ Interact 1:201-214

> Ren JS, Ross AH (2005) Environmental influence on mussel growth: a dynamic energy budget model and its application to the greenshell mussel Perna canaliculus. Ecol Modell 189:347-362

Ren JS, Stenton-Dozey J, Plew DR, Fang J, Gall M (2012) An ecosystem model for optimizing production in integrated multitrophic aquaculture systems. Ecol Modell 246: $34-46$

Rey F, Aure J, Danielssen DS (2007) Temporal and spatial distribution of nutrients. In: Sætre R (ed) The Norwegian Coastal Current. Tapir Academic Press, Trondheim

Sanderson JC, Cromey CJ, Dring MJ, Kelly MS (2008) Distribution of nutrients for seaweed cultivation around salmon cages at farm sites in north-west Scotland. Aquaculture 278:60-68

> Sanderson JC, Dring MJ, Davidson K, Kelly MS (2012) Culture, yield and bioremediation potential of Palmaria palmata (Linnaeus) Weber \& Mohr and Saccharina latissima (Linnaeus) C. E. Lane, C. Mayes, Druehl \& G. W. Saunders adjacent to fish farm cages in northwest Scotland. Aquaculture 354/355:128-135

Scheffer M, Baveco JM, DeAngelis DL, Rose KA, van Nes EH (1995) Super-individuals a simple solution for model- 
ling large populations on an individual basis. Ecol Modell 80:161-170

Shi J, Wei H, Zhao L, Yuan Y, Fang J, Zhang J (2011) A physical-biological coupled aquaculture model for a suspended aquaculture area in China. Aquaculture 318: 412-424

Sjøtun K (1993) Seasonal lamina growth in two age groups of Laminaria saccharina (L.) Lamour. in western Norway. Bot Mar 36:433-441

Skarbøvik E, Stålnacke P, Selvik JR, Aakerøy PA, Høgåsen T, Kaste Ø (2012) Elvetilførselsprogrammet (RID) - 20 års overvåking av tilførsler til norske kystområder (1990-2009). NIVA report no. 6235-2011, NIVA, Oslo

Skarðhamar J, Svendsen H (2005) Circulation and shelfocean interactions off North Norway. Cont Shelf Res 25: $1541-1560$

Skogen MD, Eknes M, Asplin LC, Sandvik AD (2009) Modelling the environmental effects of fish farming in a Norwegian fjord. Aquaculture 298:70-75

Slagstad D, McClimans TA (2005) Modeling the ecosystem dynamics of the Barents Sea including the marginal ice zone. I. Physical and chemical oceanography. J Mar Syst 58:1-18

Slagstad D, Tande K, Wassmann P (1999) Modelled carbon fluxes as validated by field data on the north Norwegian shelf during the productive period in 1994. Sarsia 84: 303-317

Statistics Norway (2012) SSB: tables and charts, aquaculture. Available at: www.ssb.no (accessed 10 January 2013)

Editorial responsibility: Alejandro Buschmann, Puerto Montt, Chile
Stevens CL, Petersen JK (2011) Turbulent, stratified flow through a suspended shellfish canopy: implications for mussel farm design. Aquacult Environ Interact 2:87-104

Støle-Hansen K, Slagstad D (1991) Simulations of currents, ice melting and vertical mixing in the Barents Sea using a 3D baroclinic model. Polar Res 10:33-44

Trancoso AR, Saraiva S, Fernandes L, Nina P, Leitao P, Neves R (2005) Modelling macroalgae using a 3D hydrodynamic-ecological model in a shallow, temperate estuary. Ecol Modell 187:232-246

Troell M, Joyce A, Chopin T, Neori A, Buschmann AH, Fang JG (2009) Ecological engineering in aquaculturePotential for integrated multi-trophic aquaculture (IMTA) in marine offshore systems. Aquaculture 297:1-9

> Volent Z, Johnsen G, Sigernes F (2007) Kelp forest mapping by use of airborne hyperspectral imager. J Appl Remote Sens 1:011503-011521

> Wang X, Olsen LM, Reitan KI, Olsen Y (2012) Emission of nutrient wastes from Norwegian salmon aquaculture: nutrient loading of receiving waters and potential for integrated multi-trophic aquaculture. Aquacult Environ Interact 2:267-283

> Wargacki AJ, Leonard E, Nyan Win MN, Regitsky DD and others (2012) An engineered microbial platform for direct biofuel production from brown macroalgae. Science 335:308-313

> Wassmann P, Slagstad D, Riser CW, Reigstad M (2006) Modelling the ecosystem dynamics of the Barents Sea including the marginal ice zone. II. Carbon flux and interannual variability. J Mar Syst 59:1-24

Submitted: January 11, 2013; Accepted: June 18, 2013 Proofs received from author(s): August 8, 2013 